\title{
Internal framework and geochemistry of the Carboniferous Huaco granite pluton, Sierra de Velasco, NW Argentina
}

\author{
*Fernando G. Sardi ${ }^{1}$, Pablo Grosse ${ }^{2}$, Mamoru Murata ${ }^{3}$, Rafael Pablo Lozano Fernández ${ }^{4}$ \\ 1 Instituto Superior de Correlación Geológica (INSUGEO-CONICET), Miguel Lillo 205 (4000), San Miguel de Tucumán, Argentina. \\ fgsardi@csnat.unt.edu.ar \\ 2 Consejo Nacional de Investigaciones Cientificas y Técnicas (CONICET) and Fundación Miguel Lillo, Miguel Lillo 251 (4000), San \\ Miguel de Tucumán, Argentina. \\ pablogrosse@yahoo.com \\ 3 Naruto University of Education, Department of Geosciences, 7772-8502, Tokushima, Japan. \\ atarumm@naruto-u.ac.jp \\ ${ }^{4}$ Museo Geominero, Instituto Geológico y Minero de España, Ríos Rosas 23, 28003, Madrid, Spain. \\ r.lozano@igme.es \\ * Corresponding author: fgsardi@csnat.unt.edu.ar
}

\begin{abstract}
The A-type Huaco granite pluton of the Velasco range (Sierras Pampeanas of northwest Argentina) is formed by three coeval granitic facies and contains subordinate coeval-to-late facies, as well as enclaves, dikes and stocks that show different temporal relations, textures and compositions. The dominant facies (Regional Porphyritic Granite; RPG) is a porphyritic two-mica monzo- to syenogranite, with abundant microcline megacrysts up to $12 \mathrm{~cm}$ in size. It was emplaced in a dominant extensional setting and has a mainly crustal source but with participation of a mantle-derived component. The RPG transitions towards two coeval and co-genetic granite facies, at its margins (Border Granite; BG) and around Be-pegmatites (Adjacent Porphyritic Granite; APG). These two facies have a finer-grained texture and smaller and less abundant megacrysts. They are also monzo- to syenogranites, but a slight decrease in the biotite/muscovite ratio is observed from the BG to the RPG to the APG. Trace element modeling suggests that the RPG, BG and APG differentiated from the same magma source by fractional crystallization. Temporally older mafic (ME) and felsic (FE) enclaves are common in the pluton. The ME can be considered partially assimilated remnants of a mafic component in the genesis of the RPG, whereas the FE seem to be remnants of premature aplites. Other subordinate rocks intrude the RPG and are, hence, temporally younger: felsic dikes (FD), dioritic dikes (DD) and equiganular granites $(\mathrm{EqG})$ are clearly posterior, whereas coeval-to-late Be-pegmatites $(\mathrm{BeP})$ and orbicular granites $(\mathrm{OG})$ formed during the final stages of crystallization of the pluton. The BeP, OG and FD indicate the presence of abundant water and volatiles. The EqG form small stocks that intrude the RPG and were possibly originated from purely crustal sources. The DD probably correspond to a younger unrelated episode of mafic magmatism.
\end{abstract}

Keywords: Graniticfacies, REE and LIL composition,Fractional crystallization model, Huaco granite, Velasco range, Sierras Pampeanas.

RESUMEN. Estructura interna y geoquímica del plutón granítico carbonífero de Huaco, Sierra de Velasco, NW de Argentina. El Plutón Huaco, ubicado en la sierra de Velasco (en Sierras Pampeanas del noroeste de Argentina), es de afinidad granítica A y está conformado por tres facies graníticas y contiene varias rocas ígneas subordinadas, las que muestran diferentes relaciones temporales, texturas y composiciones. La facies granítica dominante (Granito Porfírico Regional; RPG) es un monzo-sienogranito de dos micas, de textura porfírica con abundantes megacristales de microclino que pueden alcanzar hasta $12 \mathrm{~cm}$ de longitud. Ha sido emplazado en un marco tectónico dominantemente extensional y habría tenido una fuente de origen cortical pero también con participación de componentes mantélicos. En los bordes del Plutón Huaco y envolviendo a pegmatitas de berilo contenidas en el mismo (BeP), se reconocen las facies cogenéticas BG y APG respectivamente, las cuales tienen contacto transicional con el RPG. Estas dos facies tienen textura de grano 
más fino y megacristales de menor tamaño y menos abundante que la unidad principal RPG. También son de composición monzo-sienogranítica y se observa un decrecimiento de la relación biotita/muscovita en el sentido BG-RPG-APG. Estas tres facies graníticas cogenéticas habrían sido formadas por procesos de cristalización fraccionada a partir de un mismo magma de acuerdo al modelado geoquímico utilizando elementos traza. Además, el plutón contiene enclaves máficos (ME) y félsicos (FE) los cuales se formaron temporalmente con anterioridad a la facies granítica dominante. Los ME pueden ser considerados como remanentes asimilados de un componente máfico durante la génesis del RPG, mientras que los FE podrían corresponder a remanentes de aplitas prematuras. Otras rocas subordinadas intruyen al RPG y por lo tanto son consideradas temporalmente posteriores: diques félsicos (FD), diques dioríticos (DD) y granitos de texturas equigranulares $(\mathrm{EqG})$ son claramente posteriores, mientras que las BeP y un granito orbicular (OG) se formaron durante los estadios finales de cristalización del plutón. Las BeP, OG y FD indican la presencia de abundante agua y volátiles. Los EqG forman pequeños stocks que intruyen al RPG y se habrían formado a partir de una fuente puramente cortical. Los DD probablemente correspondan a un episodio independiente más joven de magmatismo máfico.

Palabras clave: Elementos trazas, Modelo de cristalización fraccionada, Facies granítica, Granito Huaco, Sierra de Velasco, Sierras Pampeanas.

\section{Introduction}

Granitic plutons usually display compositional and/or textural heterogeneities at different scales and magnitudes, which are commonly referred to as internal "facies". Besides, temporally previous/early and/or posterior/later magmatic rocks are commonly included within the main or dominant granitic facies. In the field, these subordinate rocks are found as dikes, enclaves, small stocks, pegmatites, lenses or pods, or irregular bodies of varying dimensions, with either sharp or diffuse contacts with the main granitic facies. The study of these subordinate rocks and their relationships with the main granitic facies can give insights into the processes that formed the pluton and its magmatic evolution (e.g., Smith et al., 1999; Breiter et al., 2005; Černý et al., 2005).

An example of such plutons with a varied internal framework is the Lower Carboniferous Huaco Pluton, part of the Velasco Range in the Sierras Pampeanas of NW Argentina. It is formed predominantly of porphyritic syeno- to monzogranites and contains several distinct subordinate facies and associated magmatic rocks with variable morphologies, compositions, textures and temporal relations. Several previous studies have described the main features of this pluton and some of its minor facies (Grosse and Sardi, 2005; Grosse et al., 2009; Sardi et al., 2010, 2011; Dahlquist et al., 2010, 2013) as well as some of the associated rocks, for example, Be-pegmatites (Cravero, 2005; Sardi et al., 2015), an orbicular granite (Quartino and Villar Fabre, 1962; Grosse et al., 2010) and the La Chinchilla stock (Grosse et al., 2005, 2009; Macchioli Grande et al., 2015). However, none of these previous studies have considered all of the facies and associated magmatic rocks and their temporal and genetic links. In this paper, we revise and present new field, petrographic and geochemical data for each of the facies and related magmatic rocks of the Huaco pluton, in order to determine their distinctive features and deduce the genetic links among them.

\section{Geology of the Velasco Range}

The Velasco range, located in La Rioja province of NW Argentina (Fig. 1a), is one of the largest ranges of the Sierras Pampeanas geologic province, which is characterized by extensive outcrops of crystalline basement composed of Upper Precambrian to Ordovician metamorphic rocks (e.g., Rossi et al., 2002; Larrovere et al., 2011) and Ordovician to Lower Carboniferous igneous, mainly granitoid, rocks (e.g., Toselli et al., 1986, 2002; Rapela et al., 2001; Dahlquist et al., 2010, 2013; Alasino et al., 2012).

The Velasco range is formed essentially by granitoids (Grosse et al., 2003, 2011; Báez et al., 2005; Toselli et al., 2005, 2006). Only a small portion of the range is occupied by outcrops of low to high grade metamorphic rocks, which are recognized as the La Cébila Formation (González Bonorino, 1951) and more recently as the La Cébila Metamorphic Complex (LCMC; Verdecchia, 2009), of Early (-Middle) Ordovician age (Verdecchia et al., 2007, 2011) (Fig. 1b). The metamorphic rocks consist of a sequence of phyllites, meta-quartzites, and minor micaceous and quartz-micaceous schists, gneiss and migmatites (Verdecchia and Baldo, 2010; De Los Hoyos et al., 2011; Larrovere et al., 2012). 


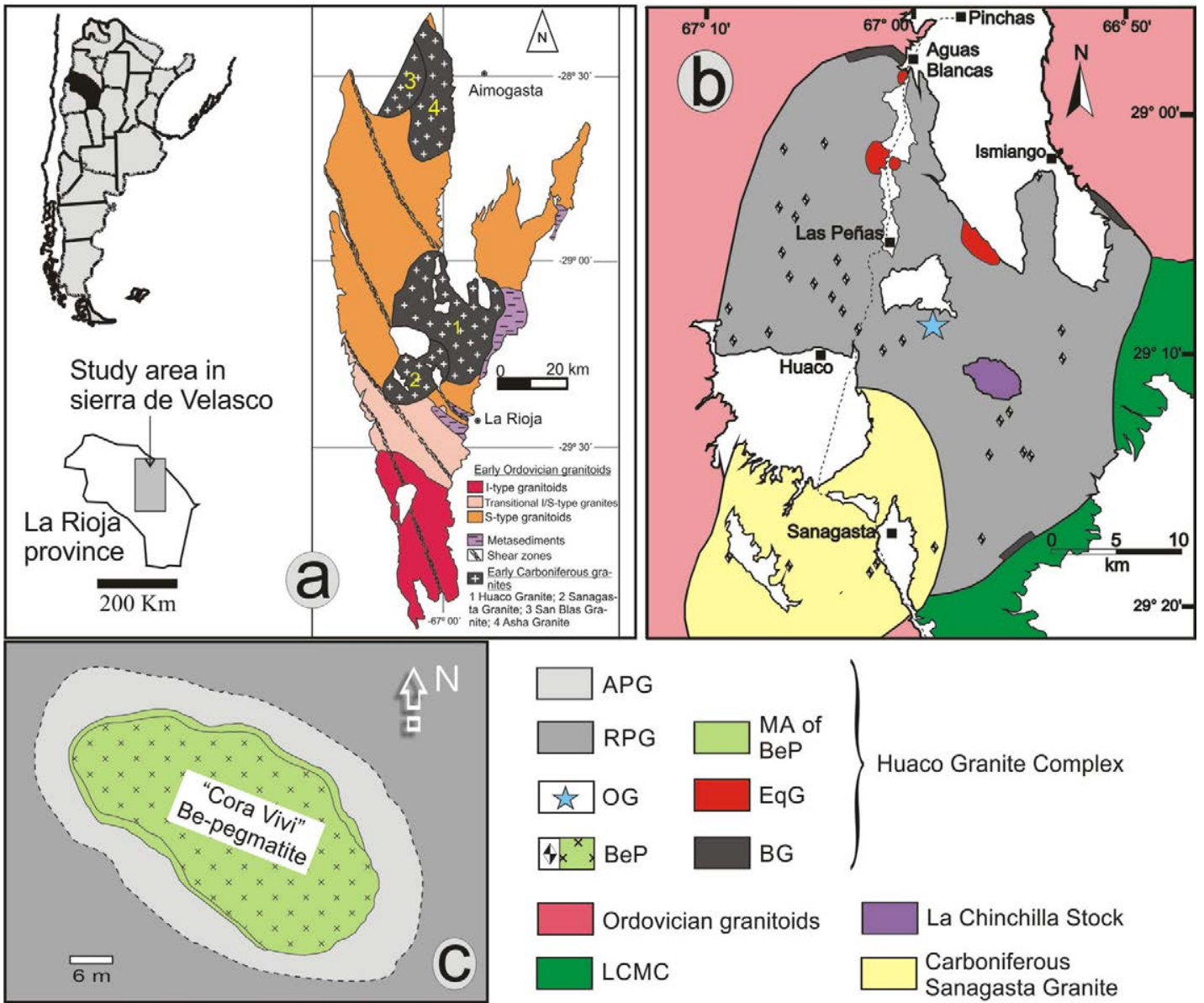

FIG. 1. a. Simplified geologic map of the sierra de Velasco (taken to Grosse et al., 2011); b. Geological map of the study area, NW Argentina, modified from Sardi et al. (2010); c. Cora Vivi Be-Pegmatite as example to show specifically the APG and MA facies. RPG: Regional Porphyritic Granite; BG: Border Granite; APG: Adjacent Porphyritic Granite; BeP: Be-pegmatite; MA: Marginal Aplite of the Be-Pegmatite; EqG: Equigranular Granites; OG: Orbicular granite; LCMC: La Cébila Metamorphic Complex.

Two pulses of magmatism are found in the Velasco range, Ordovician and Lower Carboniferous (Pankhurst et al., 2000; Toselli et al., 2007; Dahlquist et al., 2013). The Ordovician magmatic episode, linked to the Famatinian magmatic arc (e.g., Pankhurst et al., 1998), originated peraluminous S-type porphyritic granitoids on the northwestern and western flanks of the Velasco range, and metaluminous to weakly peraluminous I-type granodiorites and tonalites on the southern portion of the range (Bellos, 2005; Rossi et al., 2005a; Grosse et al., 2011; Bellos et al., 2015). The Ordovician granitoids were affected by dynamic metamorphism that generated NNW-SSE-trending ductile shear zones of regional extension. Shear zones dated at neighboring ranges constrain the timing of deformation to the Silurian-Early Devonian (e.g., Höckenreiner et al., 2003) (Fig. 1a).

The Lower Carboniferous magmatic episode produced post-tectonic granites that intrude the deformed Ordovician granitoids and metamorphic rocks of the LCMC. In the northern part of the range, the Asha and Santa Cruz granites have yielded ages of $361 \pm 4$ and $354 \pm 4 \mathrm{Ma}$ (U-Pb on monazite, Toselli et al., 2011), whereas the San Blas pluton has yielded an age of $340 \pm 3 \mathrm{Ma}$ (U-Pb on zircon, SHRIMP, Dahlquist et al., 2006). In the central part of the range (Fig. 1b), the Huaco and Sanagasta granites have yielded ages of 350 to $358 \mathrm{Ma}$ and $353 \pm 1 \mathrm{Ma}$, respectively (U-Pb on monazite; Grosse et al., 2009). 


\section{Huaco Granite Pluton}

The sub-ellipsoidal ( 40x30 km) Huaco granite pluton occupies an area of around $620 \mathrm{~km}^{2}$ in the central-eastern part of the Velasco range (Fig. 1a, b). It is formed predominantly by two-mica porphyritic syeno- to monzogranites (Huaco granite s.l.; Grosse and Sardi, 2005; Grosse et al., 2009). It is in contact to the SW with another Lower Carboniferous pluton, the Sanagasta granite pluton (Grosse et al., 2009) (Fig. 1b).

Grosse et al. (2009) determined that the main facies of the Huaco granite is silica- and potassiumrich, ferroan, alkali-calcic to slightly calc-alkalic, and moderately to weakly peraluminous (ASI: 1.06-1.18). Furthermore, Grosse et al. (2009) concluded, based on isotopic data, that the Huaco granite has a mainly crustal source, but with some participation of a more primitive, possibly mantlederived, component. The Huaco granite pluton has several characteristics indicating it is an A-type granite (e.g., Collins et al., 1982; Whalen et al., 1987; Eby, 1990, 1992): ferrous affinity (high Fe/Mg ratios), low $\mathrm{CaO}, \mathrm{Sr}$ and $\mathrm{Ba}$ contents, high contents in trace elements such as $\mathrm{Ga}, \mathrm{Nb}, \mathrm{Ta}, \mathrm{Y}$ and HREE, and high $\mathrm{FeO} / \mathrm{MgO}$ ratios (Abdel Rahman, 1994) and $\mathrm{F}$ and $\mathrm{Cl}$ contents (Muñoz, 1984) in biotites (Grosse, 2007; Grosse et al., 2009; Dahlquist et al., 2010). However, the geochemical composition of the pluton is more compatible with a post-orogenic environment than with an anorogenic environment (Grosse, 2007; Grosse et al., 2009).

Both the Huaco and Sanagasta granites are host to the Be-pegmatites of the Velasco Pegmatitic District (Sardi et al., 2002, 2015). The geochemical evolutionary trend from the main facies of the Huaco granite towards the Be-pegmatites has been studied by Sardi et al. $(2010,2011)$. The Huaco granite consists of several facies and associated rocks which are described in the next section.

\section{Internal Lithological Framework of the Huaco Granite Pluton}

\subsection{Occurrence and petrography}

The Huaco granite pluton is composed of a main and dominant porphyritic facies, previously studied by several authors (see above). Following Sardi et al. (2010), we name the main facies Regional Porphyritic
Granite (RPG). This main facies transitions towards two coeval facies, at the margins of the pluton (Border Granite; BG) and around Be-pegmatites (Adjacent porphyritic granite; APG) (Figs. 1c and 2a). Two more facies found within the main RPG can be considered as coeval-to-late facies (Fig. 1b, $\mathrm{c}$ and a): Be-pegmatites (BeP) and an orbicular granite pod (OG).

In addition, other magmatic rocks are included in the Huaco granite pluton and can be temporally identified as early or posterior units spatially related to the main facies (RPG). The former are enclaves of either mafic (Mafic Enclaves; ME) or felsic compositions (Felsic Enclaves; FE), whereas the posterior rocks are mafic dikes (Dioritic Dikes; DD), felsic dikes (Felsic Dikes; FD) and equigranular leucogranite intrusive stocks (Equigranular Granites; $\mathrm{EqG}$ ), including the La Chinchilla stock (Figs. 1b and $2 b$ ).

\subsubsection{The main facies (RPG)}

Regional Porphyritic Granite (RPG): it consists of syeno- to monzogranites with a porphyritic texture resulting from abundant idiomorphic microcline megacrysts immersed in a medium to coarse grained equigranular groundmass (Fig. 3a). The megacrysts reach sizes of up to $12 \mathrm{~cm}$ and their abundance varies between 24 and 39\%. The mineralogy is quartz (25-39\%), usually twinned plagioclase (18-31\%), twinned and often perthitic interstitial microcline (2-14\%), biotite (4-10\%) with inclusions of zircon and apatite, muscovite (2-6\%), idiomorphic apatite (up to $0.5 \%$ ) and zircon, monazite, opaque minerals, and occasionally fluorite ( $<1 \%$ ) (Grosse et al., 2009).

\subsubsection{The coeval facies (BG and $A P G)$}

These facies have been studied previously by Sardi et al. (2010 and 2011). They include:

Border Granite (BG): this is the marginal facies of the RPG and occurs in the northern and eastern margins of the Huaco granite pluton (Fig. 1b). It is approximately $100 \mathrm{~m}$ wide and grades transitionally towards the RPG (Fig. 2a). The BG is characterized by a finer-grained groundmass and smaller and less abundant megacrysts compared to the RPG (Fig. 3b). Its mineralogy is quartz (34-40\%), twinned and zoned plagioclase (23-34\%), twinned and perthitic microcline (19-33\%), biotite (5-7\%) and muscovite (2-4\%). Apatite, zircon and opaque minerals are usually included in biotite (Sardi et al., 2011). 

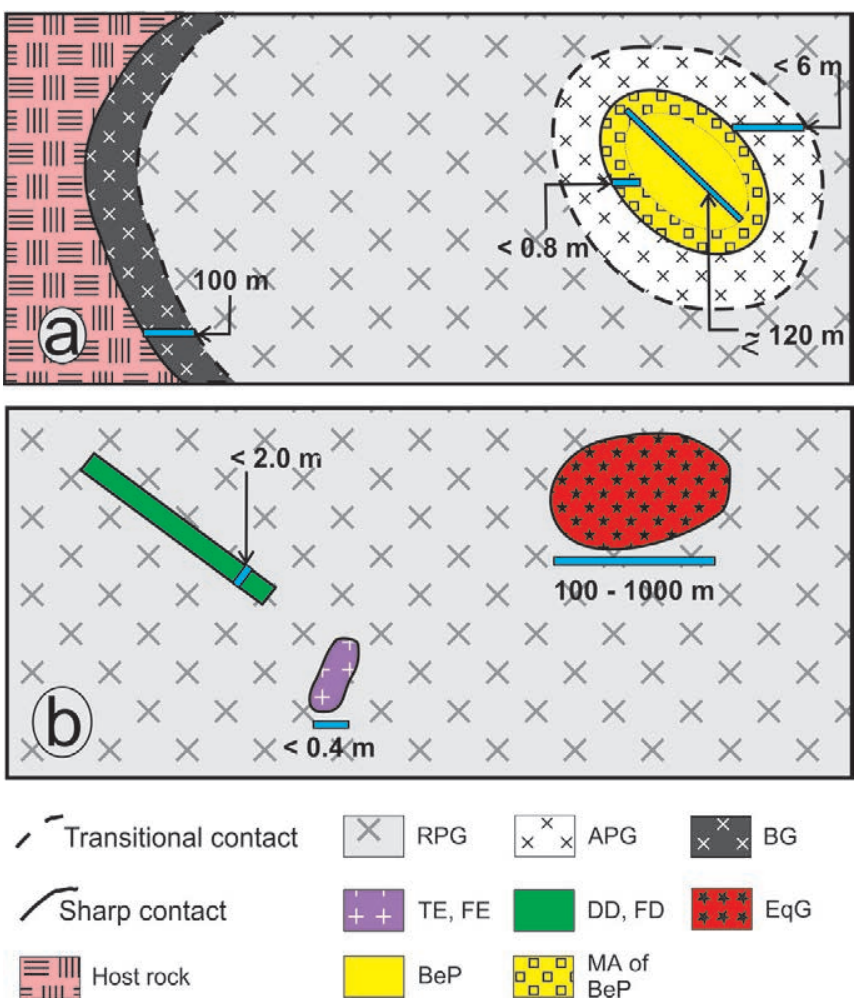

FIG. 2. Schematic graphical representation of the different facies and associated rocks found in the Huaco granite pluton, Velasco range, NW Argentina. a. RPG, BG, APG, BeP and MA; b. RPG, ME-FE, DD-FD and EqG. RPG: Regional Porphyritic Granite; BG: Border Granite; APG: Adjacent Porphyritic Granite; ME: Mafic Enclave; FE: Felsic Enclave; BeP: Be-pegmatite; MA: Marginal Aplite of the Be-Pegmatite; DD: Dioritic Dike; FD: Felsic Dike; EqG: Equigranular Granites.

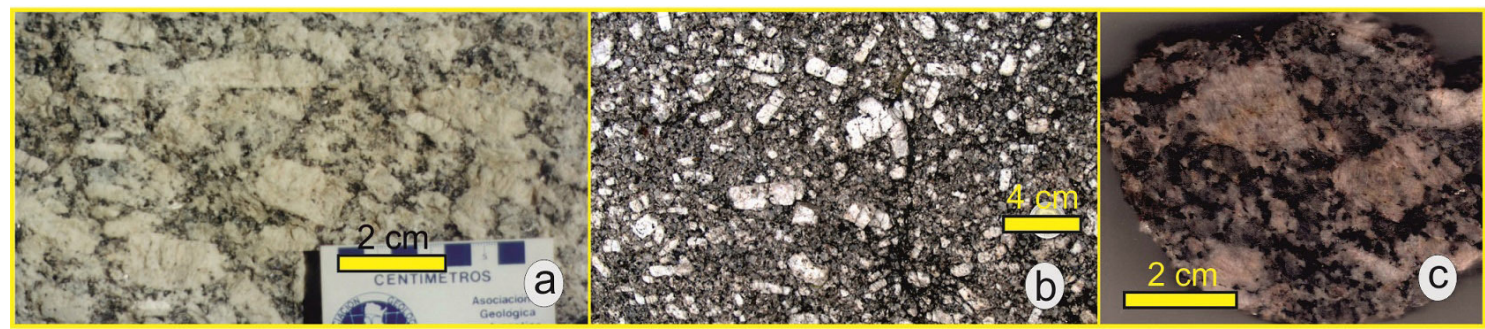

FIG. 3. Macroscopic texture of the main and coeval facies. a. RPG (taken from Sardi et al., 2015); b. BG; c. APG.

Adjacent Porphyritic Granite (APG): this facies surrounds the Be-pegmatites for distances not greater than $6 \mathrm{~m}$ from the pegmatite margins (Fig. 2a). Similar to the BG, the APG also has a finer-grained groundmass and less abundant (average value $\sim 29 \%$ ) and smaller ( $<4 \mathrm{~cm})$ microcline megacrysts compared to the RPG (Fig. 3c). Also, it has higher quartz (28-56\%) and microcline (26-52\%) contents and less plagioclase (10-24\%). A slight increase of muscovite and a decrease of biotite are also observed. Minor phases are apatite, zircon, monazite, and occasionally fluorite.

\subsubsection{The coeval-to-late facies (BeP and $O G$ ) \\ Be-pegmatites $(\mathrm{BeP})$ : they are lens-shaped with the main axis length up to $140 \mathrm{~m}$ (Sardi et al., 2015).}


They are commonly zoned, showing an aplitic or leucogranitic border zone, an intermediate pegmatitic zone composed mainly of K-feldspar and accessory minerals (beryl, apatite, triplite and muscovite), and a quartz core. The outer thin rim of the Be-pegmatites (Marginal Aplite of the Pegmatites, or MA, following Sardi et al., 2010) is in sharp contact with the APG and usually grades inward towards the Be-pegmatite zone. It commonly consists of aplites or more rarely of muscovite-rich equigranular leucogranites. The width of the MA is variable, but not greater than $0.8 \mathrm{~m}$. Its mineralogy is quartz (35-44\%), perthitic microcline and twinned plagioclase in similar amounts (16-27\% and $19-33 \%$, respectively); muscovite $(\leq 10 \%)$ is the main accessory mineral, whereas biotite is scarce and sometimes absent; fluorite is recognized occasionally (around 1\%). Columbite-tantalite is occasionally found (Sardi et al., 2015).

Orbicular Granite (OG): it is a small (65x15 m), irregularly shaped body located in the central part of the Huaco pluton (Fig. 1b). It has been studied by Quartino and Villar Fabre (1962) and Grosse et al. (2010). The OG consists of ellipsoid-shaped orbicules of 3 to $15 \mathrm{~cm}$ immersed in an aplitic-pegmatitic matrix. The orbicules consist of a core formed by a K-feldspar megacryst, partially to totally replaced by plagioclase, and alternating layers of radial and plumose plagioclase crystals and tangentially oriented biotite rings (Grosse et al., 2010). Grosse et al. (2010) conclude that the orbicular granitoid formed in situ in a pocket of evolved and volatilerich melt segregated from the surrounding partially crystallized Huaco granite, possibly via a filter pressing mechanism.

\subsubsection{Enclaves ( $M E$ and $F E$ )}

Mafic Enclaves (ME): they are dark and small, with sizes mostly under $20 \mathrm{~cm}$ (Fig. 4a), and rarely up to $50 \mathrm{~cm}$. They usually have rounded and oval shapes, occasionally being very stretched-out parallel

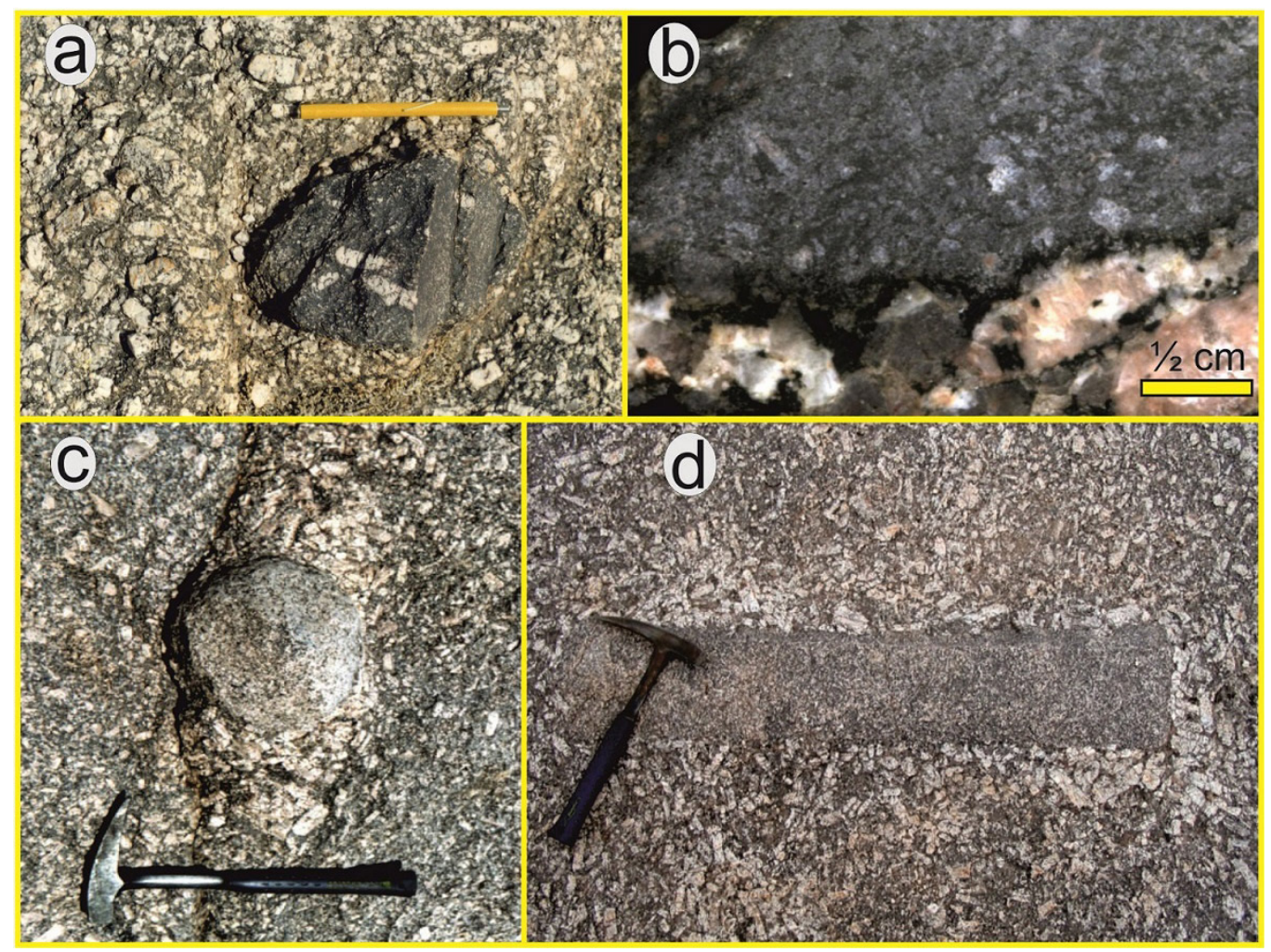

FIG. 4. Mafic and felsic enclaves within the Huaco granite pluton (RPG facies). a-b. ME, showing assimilation of megacrystals of microcline from host-rock; c-d. FE with rounded and rectangular shape, respectively; in both examples the RPG megacrsyts accumulate around the enclaves. 
to the magmatic flow. The contact with the host RPG is sharp. They commonly contain xenocrysts and xeno-megacrysts probably incorporated from the host granite magma (Fig. 4a and b).

The ME have predominantly tonalite compositions and fine-grained equigranular textures $(0.1$ to $0.5 \mathrm{~mm})$. They are very rich in biotite, varying in abundance from $10 \%$ to $50 \%$. Apatite is relatively abundant and is found as elongated prisms and needles included mostly in quartz and plagioclase. The content of opaque minerals is roughly proportional to the abundance of biotite and ranges from $\sim 1 \%$ to $10 \%$; pyrite, ilmenite and magnetite have been identified.

Felsic Enclaves (FE): these enclaves can reach $2 \mathrm{~m}$ in size. They have irregular or oval shapes and rounded borders (Fig. 4c), or more rarely straight sides (Fig. 4d). They are gray to light pink with equigranular textures, either fine-grained (0.3-1.5 $\mathrm{mm})$ or fine-to-medium-grained $(0.7-5.0 \mathrm{~mm})$. Commonly, the microcline megacrystals of the RPG accumulate around the FE (Fig. 4 c, d), suggesting an early formation for the enclaves.

Felsic enclaves are syenogranites with quartz (33-34\%) and perthitic microcline (41-45\%). Both minerals are xenomorphic. Plagioclase (15-19\%) is found as small subidiomorphic twinned crystals. Muscovite is the main accessory mineral (5-7\%) while biotite is scarce $(<2 \%)$. Apatite and zircon are very scarce and are included in biotite.

\subsubsection{Dikes (DD and FD)}

Dioritic Dikes (DD): according to field observations of Grosse (2007) and Dahlquist et al. (2010), the Huaco granitic pluton is cut by scarce dioritic dikes. They are black, fine grained (0.1-0.3 mm), up to $3 \mathrm{~m}$ wide and are in sharp contact with the RPG. Twinned sub-idiomorphic plagioclase is the most abundant mineral, commonly altered to sericite. Mafic minerals are found in an abundance of 20 to $30 \%$. Biotite is the most abundant of them and it is found as subhedral sheets with typical pleocroism, generally altered to chlorite. Other mafic minerals present are hornblende, titanite and opaque minerals. Apatite forms small elongated prisms and needles, although in smaller abundances than in mafic enclaves. Secondary calcite is also observed.

Felsic Dikes (FD): they are usually straight and are in sharp contact with the RPG (Fig. 5a and b). They are aplitic (20-30 cm in width), (Fig. 5a) with a fine-grained equigranular texture (0.1 to $1.5 \mathrm{~mm})$, although one slightly porphyritic leucogranitic dike was found ( $<2 \mathrm{~m}$ in width) (Fig. $5 \mathrm{~b}$ ). They are monzogranitic, with quartz (31\%), microcline (28-32\%) and plagioclase (27-35\%) as essential minerals, and muscovite (6-10\%) as the main accessory mineral; biotite is very scarce $(<1 \%)$.

The leucogranitic dike contains small microcline megacrysts (size $\sim 1.3 \mathrm{~cm}$; proportion $\sim 10 \%$ ) immersed in a medium to fine-grained equigranular matrix. The modal composition is quartz ( $46 \%$ ), microcline $(29 \%)$, plagioclase $(19 \%)$, biotite and muscovite $(<2 \%)$. Garnet $(\sim 4 \%)$ has been identified in this dike; it is idiomorphic, with variable sizes from small crystals to $2.5 \mathrm{~mm}$.

\subsubsection{Equigranular granites $(E q G)$}

Equigranular Granites (EqG): the EqG (Fig. 5c) are small bodies or stocks that intrude the RPG (Fig. 5d). Their sizes vary from very small $(<100 \mathrm{~m}$ diameter) to larger stocks of more than $1 \mathrm{~km}^{2}$. They have irregular shapes and usually sharp contacts (Fig. 5e).

The EqG are felsic two-mica monzogranites (muscovite $>$ biotite). The quartz and microcline crystals have similar sizes, between 1-3 mm. Quartz (26-43\%) form xenomorphic crystals. Plagioclase (25-35\%) has sub-idiomorphic habit and polysynthetic twinning. Microcline (23-29\%) is xenomorphic and twinned after pericline-albite law. Muscovite (2-9\%) is generally more abundant than biotite $(1-5 \%)$. Tourmaline is found in abundances of up to $1 \%$ in some EqG bodies. Apatite, zircon and monazite are very scarce.

The La Chinchilla stock (Fig. 1b) is a particular $\mathrm{EqG}$ that has received special attention because of its high U content (Grosse et al., 2005, 2009; Salvatore et al., 2011, 2013; Parra et al., 2011; Morello and Aparicio González, 2013). It is a medium-grained equigranular to slightly porphyritic leucogranite (Grosse et al., 2005, 2006 and 2009) that clearly intrudes the RPG. Its mineralogy consists of quartz, plagioclase, K-feldspar, biotite, fluorite, zircon, monazite, occasional beryl and very scarce apatite.

\subsection{Geochemistry}

Geochemical analysis is based on 35 representative samples of the different facies of the Huaco granite pluton and associated magmatic rocks: 8 of the 


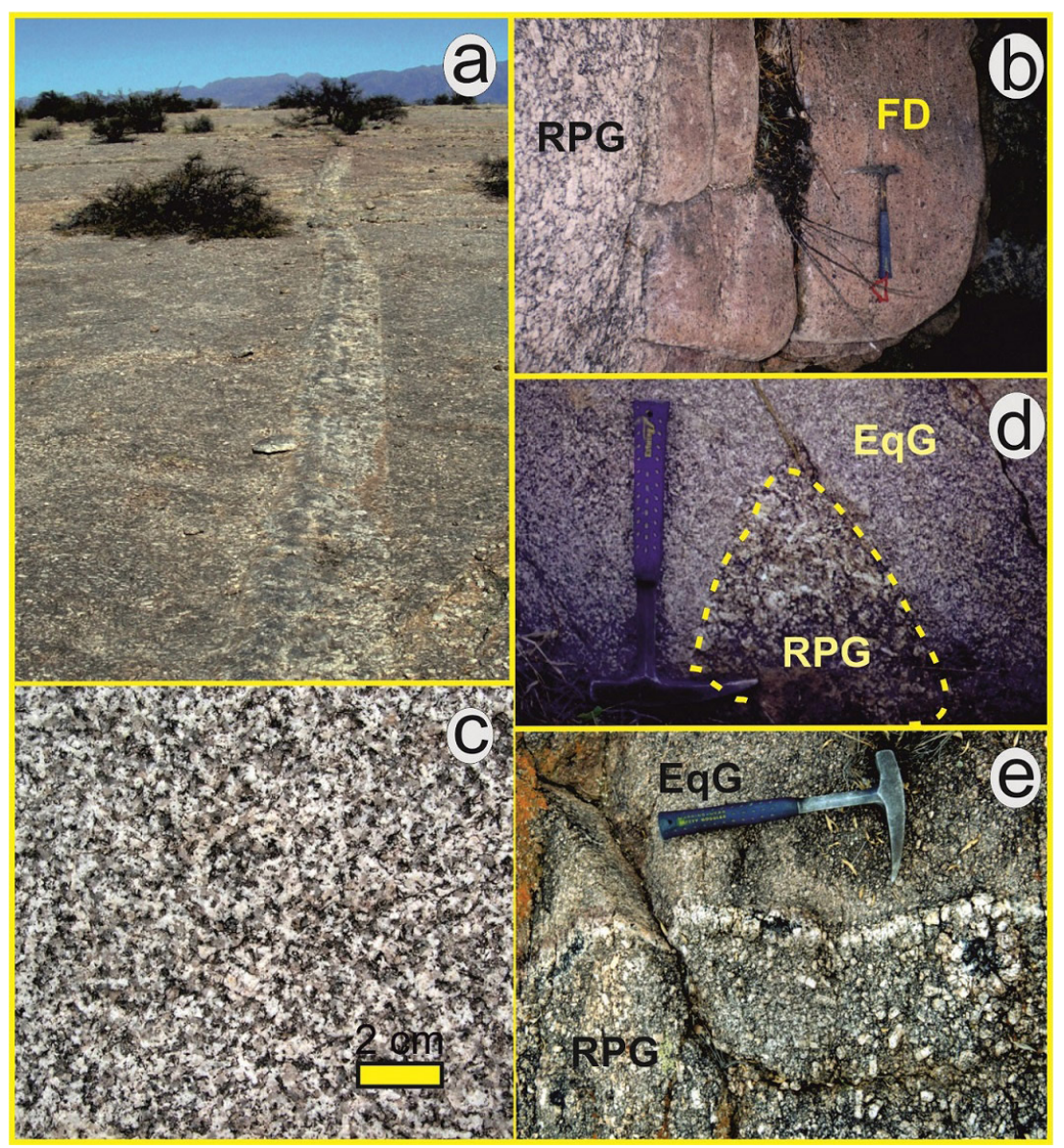

FIG. 5. Posterior facies. a. FD, straight aplite dike; b. FD, garnet-bearing slightly porphyritic granitic dike; c. Equigranular granite EqG; d. Enclave of RPG in an EqG; e. Sharp contact between RPG and an EqG.

RPG; 2 of the BG; 7 of the APG; 4 of the MA; 6 of the ME; 3 of the FE; 1 of the DD; 2 of the FD and 2 of the EqG. The analyses were performed at the laboratories of IGME (Instituto Geominero de España), Naruto University of Education (Japan), Huelva University (Spain) and ACTLAB (Canada). Major elements were determined by XRF, and trace elements by ICP-MS/AES. The analyses are shown in table 1 , and include our new data $(n=8)$ together with previously unpublished analyses of Grosse $(2007 ; n=7)$ and published data of both Grosse et al. (2009; $n=5)$ and Sardi et al. $(2010 ; n=15)$.

\subsubsection{Major elements and $R b, S r, B a$ and $C s$ compositions}

Granitoids: the facies and associated rocks of granitic composition are silica-rich, with $\mathrm{SiO}_{2}$ mostly between 68 and $75 \%$; two samples with higher contents of 78 and $81 \%$ belong to FD and MA, respectively. All rocks are peraluminous (ASI $>1$, average 1.16). The $\mathrm{FeO}_{\mathrm{t}}$ and $\mathrm{TiO}_{2}$ contents are higher in the main and coeval facies (RPG, BG and $\mathrm{APG})\left(\mathrm{FeO}_{\mathrm{t}}>1.7 \%\right.$; $\left.\mathrm{TiO}_{2} \geq 0.20 \%\right)$ than in the other rocks $\left(\mathrm{FeO}_{\mathrm{t}}<1.7 \%\right.$ and $\mathrm{TiO}_{2} \leq 0.20 \%$ ). This distinction is not so evident for $\mathrm{MgO}$, as the $2 \mathrm{EqG}$ and the $2 \mathrm{FE}$ samples are within the range of the main and coeval facies. $\mathrm{K}_{2} \mathrm{O}$ $>\mathrm{Na}_{2} \mathrm{O}$ for all cases except for two MA samples. $\mathrm{K}_{2} \mathrm{O}+\mathrm{Na}_{2} \mathrm{O}$ is between 7.4 and $9.4 \%$ for the $\mathrm{RPG}$, APG and BG facies, between 5.6 and $8.4 \%$ for the MA, and between 8.4 and $9 \%$ for the other rocks.

All samples are rich in $\mathrm{FeO}_{\mathrm{t}}$ in relation to $\mathrm{MgO}$, with $\mathrm{FeO} / \mathrm{FeO}_{\mathrm{t}}+\mathrm{MgO}$ ratios $>0.79$ (wt\%) (Fig. 6a). Most samples plot in the ferroan field of "A-type granites" in the diagram of Frost et al. (2001) (Fig. 6a) 


\begin{tabular}{|c|c|c|c|c|c|c|c|c|c|c|c|c|c|c|c|c|c|c|c|c|}
\hline \multicolumn{2}{|c|}{ Sample } & \multirow{2}{*}{$\frac{\mathbf{S i O}_{2}}{73.94}$} & \multirow{2}{*}{$\begin{array}{l}\mathbf{T i O}_{2} \\
0.23\end{array}$} & \multirow{2}{*}{$\begin{array}{r}\mathbf{A l}_{\mathbf{2}} \mathbf{O}_{3} \\
13.22\end{array}$} & \multirow{2}{*}{$\begin{array}{r}\mathbf{F e O}_{\mathbf{t}} \\
2.31\end{array}$} & \multirow{2}{*}{$\begin{array}{l}\text { MnO } \\
0.07\end{array}$} & \multirow{2}{*}{$\begin{array}{r}\text { MgO } \\
0.24\end{array}$} & \multirow{2}{*}{$\begin{array}{c}\mathrm{CaO} \\
0.88\end{array}$} & \multirow{2}{*}{$\begin{array}{c}\mathbf{N a}_{\mathbf{2}} \mathbf{O} \\
2.88\end{array}$} & \multirow{2}{*}{$\begin{array}{r}\mathbf{K}_{\mathbf{2}} \mathbf{O} \\
5.32\end{array}$} & \multirow{2}{*}{$\begin{array}{l}\mathbf{P}_{2} \mathbf{O}_{5} \\
0.15\end{array}$} & \multirow{2}{*}{$\begin{array}{c}\text { LOI } \\
0.98\end{array}$} & \multirow{2}{*}{$\begin{array}{c}\text { Total } \\
100.2\end{array}$} & \multirow{2}{*}{$\begin{array}{c}\text { ACNK } \\
1.09\end{array}$} & \multirow{2}{*}{$\begin{array}{c}\text { Cs } \\
36.6\end{array}$} & \multirow{2}{*}{$\begin{array}{c}\text { Ba } \\
185\end{array}$} & \multirow{2}{*}{$\begin{array}{c}\mathbf{R b} \\
457\end{array}$} & \multirow{2}{*}{$\begin{array}{l}\mathbf{S r} \\
46.0\end{array}$} & \multirow{2}{*}{$\begin{array}{r}\mathbf{R b} / \mathbf{S r} \\
9.93\end{array}$} & \multirow{2}{*}{$\begin{array}{c}\mathbf{B a} / \mathbf{R b} \\
0.40\end{array}$} \\
\hline & 6587 & & & & & & & & & & & & & & & & & & & \\
\hline & 6590 & 73.99 & 0.22 & 12.81 & 2.05 & 0.04 & 0.30 & 0.91 & 2.79 & 4.91 & 0.22 & 0.96 & 99.20 & 1.11 & 21.1 & 181 & 343 & 48.0 & 7.15 & 0.53 \\
\hline & 6619 & 69.80 & 0.40 & 14.38 & 3.02 & 0.06 & 0.41 & 1.51 & 3.12 & 5.46 & 0.40 & 1.16 & 99.72 & 1.04 & 19.8 & 301 & 369 & 73.0 & 5.05 & 0.82 \\
\hline \multirow{5}{*}{ ֶِ } & $6650 *$ & 72.48 & 0.43 & 13.48 & 3.02 & 0.06 & 0.49 & 1.10 & 3.01 & 4.69 & 0.34 & nd & 99.10 & 1.12 & 39.6 & 203 & 390 & 60.0 & 6.50 & 0.52 \\
\hline & $6746^{*}$ & 68.06 & 0.53 & 14.31 & 3.88 & 0.09 & 0.60 & 1.22 & 3.14 & 4.92 & 0.40 & nd & 97.15 & 1.13 & nd & 187 & 480 & 54.4 & 8.82 & 0.39 \\
\hline & $6748^{*}$ & 70.94 & 0.28 & 14.85 & 2.29 & 0.06 & 0.28 & 0.86 & 3.43 & 5.32 & 0.26 & nd & 98.57 & 1.15 & 51.8 & 204 & 412 & 52.4 & 7.86 & 0.50 \\
\hline & $6846^{*}$ & 70.92 & 0.29 & 14.26 & 2.29 & 0.07 & 0.26 & 1.12 & 3.35 & 5.65 & 0.27 & nd & 98.48 & 1.04 & nd & 256 & 361 & 66.2 & 5.45 & 0.71 \\
\hline & $6847^{*}$ & 70.86 & 0.31 & 14.27 & 2.40 & 0.06 & 0.39 & 0.75 & 2.95 & 5.63 & 0.31 & nd & 97.93 & 1.16 & 54.2 & 208 & 429 & 50.5 & 8.50 & 0.48 \\
\hline & $6931^{a}$ & 71.99 & 0.29 & 14.15 & 1.73 & 0.04 & 0.44 & 0.88 & 3.05 & 5.51 & 0.25 & 0.75 & 99.08 & 1.12 & 25.6 & 368 & 290 & 81.3 & 3.57 & 1.27 \\
\hline 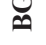 & $7697^{a}$ & 71.64 & 0.35 & 14.19 & 2.28 & 0.06 & 0.38 & 0.86 & 3.04 & 5.59 & 0.30 & 0.65 & 99.35 & 1.13 & 31.2 & 268 & 282 & 73.6 & 3.83 & 0.95 \\
\hline & $6657^{*}$ & 73.23 & 0.19 & 13.94 & 1.68 & 0.05 & 0.24 & 0.62 & 3.11 & 5.32 & 0.22 & $\mathrm{nd}$ & 98.60 & 1.16 & 31.5 & 169 & 420 & 43.2 & 9.72 & 0.40 \\
\hline & $6738^{*}$ & 70.06 & 0.35 & 14.63 & 2.93 & 0.09 & 0.41 & 0.97 & 3.45 & 5.25 & 0.37 & nd & 98.51 & 1.11 & 76.1 & 213 & 487 & 56.0 & 8.70 & 0.44 \\
\hline & $6744^{*}$ & 73.12 & 0.30 & 13.86 & 2.31 & 0.06 & 0.32 & 0.85 & 3.34 & 4.60 & 0.21 & nd & 98.97 & 1.15 & nd & 181 & 393 & 48.5 & 8.10 & 0.46 \\
\hline 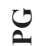 & $6842 *$ & 72.44 & 0.24 & 14.30 & 1.66 & 0.06 & 0.16 & 0.27 & 2.20 & 7.07 & 0.20 & nd & 98.60 & 1.22 & 113 & 254 & 658 & 43.0 & 15.3 & 0.39 \\
\hline 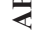 & $6924^{*}$ & 74.34 & 0.21 & 13.20 & 1.84 & 0.09 & 0.20 & 0.74 & 2.94 & 4.50 & 0.12 & nd & 98.18 & 1.19 & nd & 166 & 447 & 37.1 & 12.1 & 0.37 \\
\hline & $7122 *$ & 70.60 & 0.25 & 14.18 & 2.14 & 0.06 & 0.32 & 0.80 & 3.28 & 5.94 & 0.30 & nd & 97.87 & 1.07 & 48.1 & 223 & 485 & 94.8 & 5.12 & 0.46 \\
\hline & $7129 *$ & 70.99 & 0.22 & 14.39 & 1.94 & 0.05 & 0.28 & 0.89 & 3.52 & 5.86 & 0.23 & $\mathrm{nd}$ & 98.37 & 1.05 & 21.3 & 200 & 403 & 55.6 & 7.25 & 0.50 \\
\hline & 6615 & 81.16 & 0.04 & 10.34 & 0.50 & 0.03 & 0.04 & 0.17 & 2.63 & 2.99 & 0.14 & 0.97 & 99.00 & 1.31 & 32.6 & 28 & 329 & 7.00 & 47.0 & 0.09 \\
\hline & 7121A* & 75.01 & 0.07 & 14.07 & 0.65 & 0.05 & 0.09 & 0.60 & 5.35 & 3.02 & 0.26 & nd & 99.17 & 1.07 & 24.0 & 55 & 327 & 16.6 & 19.7 & 0.17 \\
\hline $\bar{\Sigma}$ & $7121 B^{*}$ & 73.99 & 0.06 & 14.83 & 0.73 & 0.04 & 0.09 & 0.56 & 5.22 & 2.76 & 0.26 & nd & 98.54 & 1.18 & 32.3 & 66 & 376 & 13.9 & 27.1 & 0.18 \\
\hline & $7121 C^{*}$ & 72.93 & 0.09 & 15.01 & 0.78 & 0.04 & 0.10 & 0.49 & 4.39 & 4.39 & 0.26 & nd & 98.48 & 1.17 & 31.3 & 83 & 434 & 25.0 & 17.4 & 0.19 \\
\hline & 6649 & 51.86 & 1.50 & 15.43 & 8.68 & 0.13 & 5.82 & 5.73 & 0.83 & 4.19 & 0.64 & nd & 94.81 & 0.95 & nd & 1,019 & 519 & 768 & 0.68 & 1.96 \\
\hline & 6745 & 56.59 & 0.95 & 18.09 & 7.55 & 0.16 & 3.04 & 0.36 & 0.61 & 7.09 & 0.1 & nd & 94.54 & 1.94 & nd & 390 & 360 & 26.7 & 13.5 & 1.08 \\
\hline & 6747 & 63.62 & 0.93 & 15.02 & 5.71 & 0.09 & 2.47 & 3.28 & 3.12 & 2.54 & 0.16 & nd & 96.94 & 1.08 & nd & 189 & 220 & 121 & 1.82 & 0.86 \\
\hline$\sum$ & $6877^{a}$ & 70.49 & 0.54 & 14.29 & 3.72 & 0.10 & 0.61 & 1.17 & 3.33 & 4.87 & 0.42 & 0.51 & 100.0 & 1.11 & 36.7 & 136 & 1,913 & 43.6 & 43.9 & 0.07 \\
\hline & $7728^{a}$ & 54.94 & 2.51 & 14.52 & 12.44 & 0.24 & 2.37 & 1.82 & 2.50 & 4.50 & 0.85 & 1.03 & 97.71 & 1.18 & 175 & 118 & 2,758 & 26.5 & 104 & 0.04 \\
\hline & $7734^{\mathrm{a}}$ & 62.98 & 1.19 & 15.65 & 7.57 & 0.14 & 1.22 & 2.20 & 4.41 & 2.83 & 0.60 & 0.74 & 99.53 & 1.09 & 46.9 & 123 & 356 & 48.6 & 7.33 & 0.34 \\
\hline & 6588 & 72.96 & 0.14 & 13.17 & 1.67 & 0.042 & 0.22 & 0.63 & 2.84 & 6.06 & 0.12 & 0.86 & 98.71 & 1.06 & 11.8 & 171 & 376 & 47.0 & 8.00 & 0.45 \\
\hline 됟 & 6914 & 74.44 & 0.12 & 13.68 & 1.03 & 0.03 & 0.17 & 0.36 & 2.55 & 6.14 & 0.23 & 0.60 & 99.34 & 1.19 & 26.9 & 107 & 327 & 26.0 & 12.6 & 0.33 \\
\hline & 6972 & 75.20 & 0.07 & 13.16 & 0.67 & 0.02 & 0.13 & 0.35 & 2.72 & 6.26 & 0.21 & 0.46 & 99.25 & 1.11 & 33.1 & 100 & 347 & 42.3 & 8.20 & 0.29 \\
\hline ิิ & 7742 & 56.59 & 1.73 & 15.77 & 8.23 & 0.15 & 3.81 & 4.68 & 4.15 & 3.07 & 0.67 & 1.63 & 100.5 & 0.84 & 27.8 & 222 & 131 & 477 & 0.28 & 1.69 \\
\hline & 6589 & 78.13 & 0.02 & 11.58 & 0.92 & 0.11 & 0.04 & 0.34 & 2.75 & 5.44 & 0.09 & 0.43 & 99.85 & 1.05 & 3.90 & 119 & 263 & 37.0 & 7.11 & 0.45 \\
\hline 金 & 7733 & 74.37 & 0.08 & 13.92 & 1.03 & 0.05 & 0.08 & 0.33 & 3.54 & 4.89 & 0.13 & 0.70 & 99.11 & 1.19 & 39.31 & 78 & 343 & 19.8 & 17.3 & 0.23 \\
\hline 0 & 7233 & 72.39 & 0.14 & 14.56 & 1.20 & 0.05 & 0.26 & 0.54 & 3.38 & 5.39 & 0.32 & 0.78 & 99.01 & 1.18 & 115 & 148 & 382 & 37.2 & 10.3 & 0.39 \\
\hline F्ञ & 7400 & 72.76 & 0.20 & 14.17 & 1.49 & 0.04 & 0.34 & 0.68 & 3.29 & 4.95 & 0.31 & 0.74 & 98.97 & 1.18 & 60.0 & 177 & 330 & 48.7 & 6.77 & 0.54 \\
\hline
\end{tabular}




\begin{tabular}{|c|c|c|c|c|c|c|c|c|c|c|c|c|c|c|c|c|c|c|c|c|}
\hline \multicolumn{2}{|c|}{ Sample } & $\mathbf{Y}$ & $\mathbf{L a}$ & $\mathrm{Ce}$ & Pr & Nd & Sm & Eu & Gd & $\mathbf{T b}$ & Dy & Но & Er & $\mathbf{T m}$ & $\mathbf{Y b}$ & Lu & LREE & HREE & $\mathbf{E u} / \mathbf{E u} \mathbf{u}^{*}$ & $\mathbf{L a}_{n} / \mathbf{Y} \mathbf{b}_{n}$ \\
\hline \multirow{8}{*}{ پِ } & 6587 & 65.0 & 47.4 & 107 & 12.8 & 45.8 & 10.9 & 0.82 & 9.54 & 1.95 & 12.0 & 2.25 & 5.99 & 0.97 & 5.58 & 0.74 & 225 & 39.0 & 0.25 & 5.68 \\
\hline & 6590 & 38.0 & 30.0 & 86.0 & 8.27 & 29.6 & 6.98 & 0.73 & 6.23 & 1.28 & 7.36 & 1.23 & 2.96 & 0.44 & 2.57 & 0.33 & 162 & 22.4 & 0.34 & 7.81 \\
\hline & 6619 & 44.4 & 63.6 & 139 & 16.7 & 62.5 & 13.4 & 1.46 & 10.9 & 1.83 & 9.74 & 1.64 & 4.11 & 0.57 & 3.38 & 0.44 & 297 & 32.6 & 0.37 & 12.6 \\
\hline & $6650 * *$ & 38.6 & 49.4 & 112 & 13.6 & 51.5 & 11.2 & 0.94 & 10.1 & 1.45 & 7.48 & 1.24 & 3.22 & 0.40 & 2.40 & 0.34 & 239 & 26.6 & 0.27 & 13.8 \\
\hline & $6746^{* *}$ & 44.2 & nd & nd & nd & nd & nd & nd & nd & nd & nd & nd & nd & nd & nd & nd & - & - & - & - \\
\hline & $6748^{* *}$ & 36.2 & 32.0 & 73.2 & 8.72 & 33.3 & 7.5 & 0.87 & 7.08 & 1.12 & 6.25 & 1.11 & 3.11 & 0.43 & 2.73 & 0.4 & 156 & 22.2 & 0.37 & 7.84 \\
\hline & $6846^{* *}$ & 34.6 & nd & nd & nd & nd & nd & nd & nd & nd & nd & nd & nd & nd & nd & nd & - & - & - & - \\
\hline & $6847 * *$ & 37.7 & 36.2 & 82.7 & 10.0 & 38.1 & 8.50 & 0.85 & 7.71 & 1.21 & 6.47 & 1.11 & 2.99 & 0.40 & 2.41 & 0.34 & 176 & 22.6 & 0.32 & 10.0 \\
\hline \multirow[b]{2}{*}{ بِ } & $6931^{\mathrm{a}}$ & 17.8 & 42.9 & 88.7 & 11.6 & 52.3 & 10.5 & 0.75 & 7.68 & 0.85 & 4.54 & 0.63 & 1.71 & 0.11 & 1.31 & 0.08 & 207 & 16.9 & 0.26 & 21.9 \\
\hline & $7691^{\mathrm{a}}$ & 29.6 & 34.4 & 73.0 & 9.75 & 38.5 & 7.66 & 1.12 & 6.98 & 1.17 & 6.49 & 1.19 & 3.26 & 0.48 & 2.94 & 0.45 & 164 & 23.0 & 0.47 & 7.82 \\
\hline \multirow{7}{*}{ ऐ) } & $6657^{* *}$ & 35.7 & 24.3 & 54.9 & 6.58 & 24.2 & 5.60 & 0.60 & 5.27 & 0.86 & 4.92 & 0.85 & 2.22 & 0.30 & 1.85 & 0.26 & 116 & 16.5 & 0.34 & 8.78 \\
\hline & $6738^{* *}$ & 43.3 & 39.3 & 87.9 & 10.8 & 40.6 & 8.77 & 0.97 & 8.11 & 1.28 & 7.02 & 1.27 & 3.61 & 0.49 & 3.11 & 0.44 & 188 & 25.3 & 0.35 & 8.45 \\
\hline & $6744 * *$ & 35.8 & nd & nd & nd & nd & nd & nd & nd & nd & nd & nd & nd & nd & nd & nd & - & - & - & - \\
\hline & $6842 * *$ & 43.8 & 38.1 & 85.5 & 10.3 & 38.7 & 8.38 & 1.03 & 7.24 & 1.07 & 5.1 & 0.78 & 1.89 & 0.24 & 1.42 & 0.2 & 182 & 17.9 & 0.41 & 17.9 \\
\hline & $6924^{* *}$ & 38.7 & nd & nd & nd & nd & nd & nd & nd & nd & nd & nd & nd & nd & nd & nd & - & - & - & - \\
\hline & $7122 * *$ & 40.1 & 31.8 & 71.3 & 8.77 & 33.2 & 7.41 & 0.79 & 6.88 & 1.08 & 5.99 & 1.02 & 2.73 & 0.36 & 2.32 & 0.32 & 153 & 20.7 & 0.34 & 9.17 \\
\hline & $7129 * *$ & 36.3 & 28.0 & 63.5 & 7.62 & 28.4 & 6.66 & 0.78 & 6.58 & 1.14 & 6.81 & 1.19 & 3.17 & 0.42 & 2.6 & 0.36 & 135 & 22.3 & 0.36 & 7.20 \\
\hline \multirow{4}{*}{ 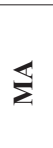 } & 6615 & 4.0 & 1.58 & 3.09 & 0.36 & 1.13 & 0.37 & 0.03 & 0.31 & 0.08 & 0.52 & 0.09 & 0.21 & 0.04 & 0.3 & 0.04 & 6.56 & 1.59 & 0.30 & 3.52 \\
\hline & $7121 A^{* *}$ & 25.2 & 2.78 & 5.88 & 0.68 & 2.44 & 0.70 & 0.13 & 0.81 & 0.19 & 1.39 & 0.28 & 0.87 & 0.14 & 1.00 & 0.14 & 12.6 & 4.82 & 0.53 & 1.86 \\
\hline & $7121 \mathrm{~B}^{* *}$ & 26.1 & 1.08 & 2.33 & 0.28 & 1.00 & 0.34 & 0.06 & 0.39 & 0.10 & 0.68 & 0.13 & 0.41 & 0.07 & 0.56 & 0.08 & 5.09 & 2.42 & 0.51 & 1.29 \\
\hline & $7121 C^{* *}$ & 29.5 & 3.42 & 7.20 & 0.86 & 3.04 & 0.84 & 0.20 & 0.93 & 0.20 & 1.33 & 0.26 & 0.79 & 0.12 & 0.92 & 0.12 & 15.6 & 4.67 & 0.70 & 2.49 \\
\hline \multirow{7}{*}{ 됙 } & 6649 & 41.1 & nd & nd & nd & nd & nd & nd & nd & nd & nd & nd & nd & nd & nd & nd & - & - & - & - \\
\hline & 6745 & 34.3 & nd & nd & nd & nd & nd & nd & nd & nd & nd & nd & nd & nd & nd & nd & - & - & - & - \\
\hline & 6747 & 29.0 & nd & nd & nd & nd & nd & nd & nd & nd & nd & nd & nd & nd & nd & nd & - & - & - & - \\
\hline & $6877^{a}$ & 33.53 & 39.11 & 83.9 & 12.2 & 45.6 & 10.2 & 0.78 & 9.28 & 1.55 & 8.02 & 1.45 & 3.47 & 0.48 & 2.64 & 0.38 & 192 & 27.3 & 0.25 & 9.90 \\
\hline & $7728^{a}$ & 49.25 & 48.76 & 98.0 & 15.2 & 65.1 & 13.6 & 1.15 & 13.3 & 2.12 & 11.8 & 2.16 & 5.36 & 0.74 & 4.25 & 0.62 & 242 & 40.4 & 0.26 & 7.68 \\
\hline & $7734^{a}$ & 51.00 & 62.70 & 122 & 18.7 & 76.9 & 15.1 & 1.32 & 14.0 & 2.26 & 12.0 & 2.20 & 5.71 & 0.80 & 4.87 & 0.73 & 297 & 42.6 & 0.28 & 8.61 \\
\hline & 6588 & 53.10 & 26.9 & 60.4 & 7.15 & 28.2 & 6.43 & 0.69 & 6.44 & 1.30 & 8.55 & 1.90 & 5.75 & 0.87 & 5.14 & 0.72 & 130 & 30.7 & 0.33 & 3.50 \\
\hline \multirow{2}{*}{ trل } & 6914 & 10.56 & 9.97 & 23.6 & 3.02 & 11.0 & 2.56 & 0.31 & 2.39 & 0.43 & 2.23 & 0.40 & 0.95 & 0.14 & 0.79 & 0.13 & 50.5 & 7.46 & 0.39 & 8.40 \\
\hline & 6972 & 6.66 & 3.37 & 7.57 & 0.70 & 3.42 & 0.82 & 0.25 & 0.91 & 0.07 & 1.15 & 0.11 & 0.58 & 0.01 & 0.47 & 0.01 & 16.1 & 3.32 & 0.89 & 4.81 \\
\hline$\hat{\mathrm{\theta}}$ & 7742 & 23.67 & 29.61 & 60.1 & 8.25 & 33.9 & 7.10 & 2.01 & 6.74 & 1.04 & 5.36 & 1.03 & 2.58 & 0.36 & 2.08 & 0.33 & 141 & 19.5 & 0.89 & 9.51 \\
\hline \multirow[b]{2}{*}{ 宝 } & 6589 & 39.40 & 5.49 & 8.28 & 0.73 & 2.38 & 0.51 & 0.72 & 0.94 & 0.37 & 4.41 & 1.55 & 6.47 & 1.24 & 8.48 & 1.22 & 18.1 & 24.7 & 3.19 & 0.43 \\
\hline & 7733 & 18.28 & 9.57 & 24.0 & 2.65 & 9.82 & 2.56 & 0.28 & 2.40 & 0.56 & 3.44 & 0.67 & 2.08 & 0.35 & 2.54 & 0.40 & 48.9 & 12.4 & 0.34 & 2.52 \\
\hline \multirow{2}{*}{$\underset{5}{\mathscr{I}}$} & 7233 & 12.74 & 11.41 & 28.70 & 3.04 & 14.0 & 3.23 & 0.24 & 2.98 & 0.43 & 2.92 & 0.39 & 1.21 & 0.05 & 1.02 & 0.03 & 60.7 & 9.03 & 0.24 & 7.52 \\
\hline & 7400 & 14.33 & 18.79 & 42.41 & 4.77 & 21.8 & 4.79 & 0.41 & 4.07 & 0.51 & 3.21 & 0.41 & 1.30 & 0.05 & 1.06 & 0.03 & 92.9 & 10.6 & 0.29 & 11.7 \\
\hline
\end{tabular}

nd: not determinated; *data from Sardi et al. (2010); ' data from Grosse et al. (2009).

**data only Y from Sardi et al. (2010).

Major elements in $\mathrm{wt} \%$ and trace elements in $\mathrm{ppm}$. ACNK Alumina saturation index. 


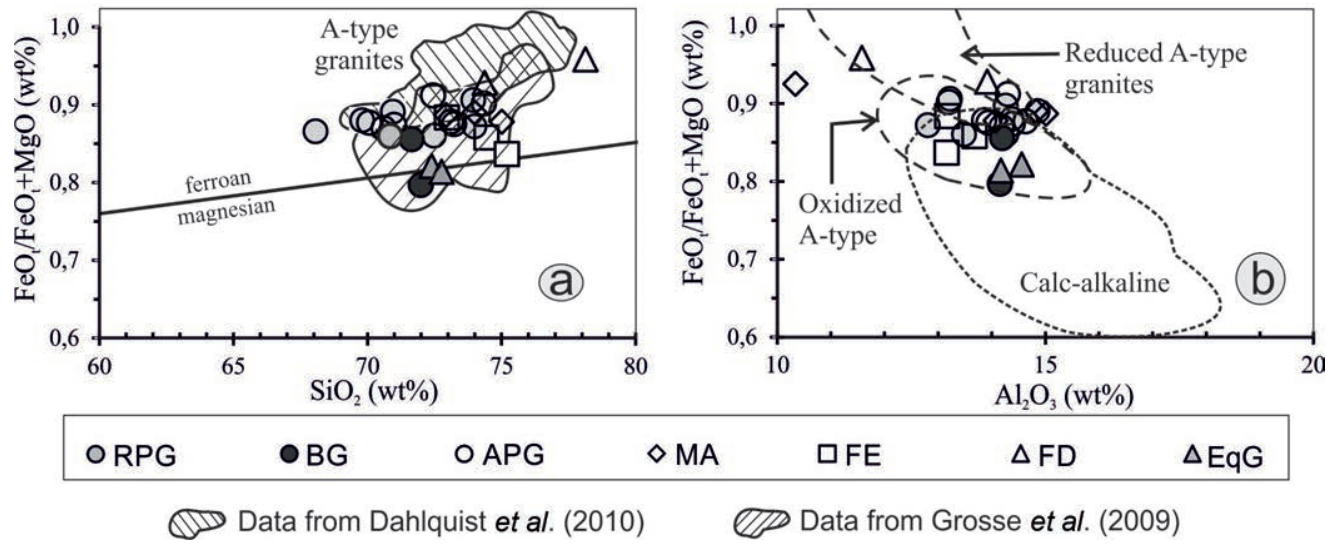

FIG. 6. Geochemical diagrams. a. $\mathrm{FeO}_{\mathrm{t}} / \mathrm{FeO}_{\mathrm{t}}+\mathrm{MgO}$ (wt\%) versus $\mathrm{SiO}_{2}(\mathrm{wt} \%$ ) with A-type granites field of Frost et al. (2001). Data of previous works on the Huaco Granite Pluton and other typical A-type granites from the Velasco range and surrounding areas are included in the diagram (Grosse et al., 2009; Dahlquist et al., 2010). b. $\mathrm{FeO} / \mathrm{FeO}+\mathrm{MgO}$ (wt\%) versus $\mathrm{Al}_{2} \mathrm{O}_{3}(\mathrm{wt} \%$ ) indicating the field of oxidized and reduced A-type granites of Dall'Agnol and Oliveira (2007).

in agreement with Grosse et al. (2009) and Dahlquist et al. (2010). In the diagram of Dall' Agnol and Oliveira (2007) (Fig. 6b) the samples plot in both the "reduced" and "oxidized" A-type granite fields.

Regarding trace element contents, the rocks show both differences and similarities. In the case of Cs, the lowest values are in samples of the FD and FE ( $\sim 4$ and $\sim 12 \mathrm{ppm}$, respectively), and the highest ones in samples of the EqG and APG ( $115 \mathrm{ppm})$. Lower $\mathrm{Rb}$ contents $(<300 \mathrm{ppm})$ are recorded in the $\mathrm{BG}$ facies and in one sample of the FD, while the highest content corresponds to a sample of the APG (658 ppm). Roughly, Ba and Sr contents gradually increase in the following sequence: MA, FD, FE, EqG, APG, RGP, BG. The BG facies contains the lowest $\mathrm{Rb} / \mathrm{Sr}$ (3.6 and 3.8) and highest $\mathrm{Ba} / \mathrm{Rb}(0.95$ and 1.27) ratios, whereas the MA contains the highest (17.4-47.0) and lowest (0.09-0.19) ratios, respectively.

Finally, the La Chinchilla stock is very rich in $\mathrm{SiO}_{2}$, weakly peraluminous, has very low $\mathrm{Ca}, \mathrm{P}, \mathrm{Fe}$ and $\mathrm{Mg}$ contents, and is strongly enriched in several trace elements, particularly $\mathrm{Li}, \mathrm{Rb}, \mathrm{Nb}, \mathrm{Ta}, \mathrm{U}, \mathrm{Th}, \mathrm{Y}$ and HREE (Grosse et al., 2009). Grosse et al. (2009), based on Nd isotopes, suggest that the La Chinchilla stock derived from a different, more primitive source compared to the Huaco granite; we do not consider it further in this study.

$M E$ and $D D$ : The 6 analyzed mafic enclaves have variable compositions that can be attributed to different degrees of assimilation and hybridization with the host rock. Three samples have low $\mathrm{SiO}_{2}$ contents $(<57 \%)$ and can be considered slightly assimilated by the granite magma, whereas one of them contains $70 \% \mathrm{SiO}_{2}$, similar to the host granite.

The ME samples have very high concentrations in $\mathrm{FeOt}$ and $\mathrm{MgO}$ and their abundances are inversely proportional to the $\mathrm{SiO}_{2}$ content. They are also rich in $\mathrm{CaO}$ and $\mathrm{P}_{2} \mathrm{O}_{5}$. The alkali contents do not vary with $\mathrm{SiO}_{2}$. The $\mathrm{FeO}_{\mathrm{t}} / \mathrm{FeO}_{\mathrm{t}}+\mathrm{MgO}$ ratios in the $\mathrm{ME}$ are variable between 0.69 and 0.86 .

The dioritic dike (DD) shows evidence of assimilation of felsic material. The analyzed sample has a low $\mathrm{SiO}_{2}$ content (56.6\%), similar to the less assimilated mafic enclaves. It presents high contents of ferromagnesian elements, $\mathrm{CaO}$, alkalis and $\mathrm{P}_{2} \mathrm{O}_{5}$. Compared to the less assimilated mafic enclaves, it is poor in $\mathrm{FeO}_{\mathrm{t}}$ and rich in $\mathrm{MgO}$, so its $\mathrm{FeO}_{\mathrm{t}} / \mathrm{FeO}_{\mathrm{t}}+\mathrm{MgO}$ ratio is very low $(0.68)$. The ASI of the DD is 0.84 . On the other hand, the DD has a composition that is very similar to mafic dikes hosted in the Carboniferous San Blas granite in the north of the Velasco range (Báez, 2006).

The Cs (37-175 ppm), Rb (220-2758 ppm), Ba (118-189 ppm) and Sr (26-121 ppm) contents in the mafic enclaves (ME) are variable, whereas the DD has values of $28 \mathrm{ppm}, 131 \mathrm{ppm}, 222 \mathrm{ppm}$ and 477 ppm, respectively.

\subsubsection{REE and $Y$ composition}

$\mathrm{Y}$ content is greater in the RPG and APG than in all other granitoid rocks, but the values of $\mathrm{Y}$ in the mafic enclaves (ME) are similar to the RPG. 
LREE>HREE is observed in all facies of Huaco granite and associated rocks, with the exception of the garnet-bearing felsic dike (sample 6589). The highest REE contents $(>170 \mathrm{ppm})$ are found in the RPG, BG, APG and ME (Table 1, Fig. 7). The RPG, BG and APG show similar chondrite-normalized $\mathrm{REE}$ patterns and $\mathrm{La}_{\mathrm{n}} / \mathrm{Yb}_{\mathrm{n}}$ ratios always $>5$. The EqG have lower REE contents but similar $\mathrm{La}_{\mathrm{n}} / \mathrm{Yb}_{\mathrm{n}}$ ratios also $>5$ (Table 1, Fig. 7). The FE, MA and FD have the lowest concentrations of REE and the lowest $\mathrm{La}_{\mathrm{n}} / \mathrm{Yb}_{\mathrm{n}}$ ratios, mostly $<5$ (Table 1, Fig. 7). $\mathrm{The} \mathrm{Eu} / \mathrm{Eu}^{*}$ ratio is $<1$ and the $\mathrm{La}_{\mathrm{n}} / \mathrm{Yb}_{\mathrm{n}}$ ratio is $>1$ for all rocks, with the exception of the FD garnetbearing sample (Table 1 and Fig. 7).

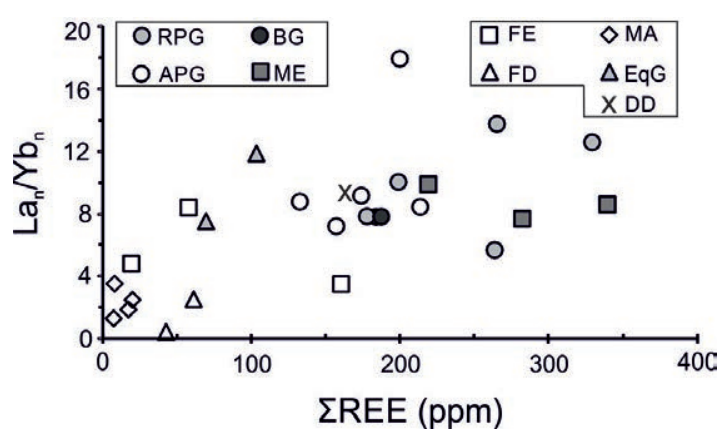

FIG. 7. $\mathrm{La}_{\mathrm{n}} / \mathrm{Yb}_{\mathrm{n}}$ * versus $\Sigma \mathrm{REE}$ orthogonal diagram. *Normalized after Nakamura (1974).

\section{Discussion}

Based on Nd and Sr isotopic data $(\varepsilon N d-2.10$ to $-4.27 ; \mathrm{Sr}^{87} / \mathrm{Sr}^{86} 0.7820$ to 0.8825$)$ and geochemical features such as high and restricted $\mathrm{SiO}_{2}$ contents, peraluminous character, high contents of LIL and other trace elements such $\mathrm{Nb}, \mathrm{Y}$ and $\mathrm{Ga}$, Grosse et al. (2009) and Dahlquist et al. (2010) suggested that the Huaco pluton, as a whole, formed from a mainly crustal source (possibly the Ordovician meta-granites), with minor participation of a mantlederived component, and intruded in a dominantly extensional setting. The study of each minor facies and associated igneous rocks can give further clues on the evolution of the granite pluton.

Both the BG and the APG are coeval with the RPG. The BG possibly formed on the walls of the magmatic chamber, whereas the APG formed around the BeP. A temporal sequence of crystallization in the order $\mathrm{BG} \rightarrow \mathrm{RPG} \rightarrow \mathrm{APG}$ is favored by the slight decrease in the biotite/muscovite ratio and by their LIL contents (see below). The finer-grained texture of the BG and APG facies compared to the RPG facies suggests faster growth rates for the $\mathrm{BG}$ and APG during slightly lower temperature conditions (e.g., Vernon, 1986).

Figures $8 \mathrm{a}$ and $\mathrm{b}$ present major and trace element variation diagrams with $\mathrm{SiO}_{2}(\mathrm{wt} \%)$ as a differentiation index for the facies and associated rocks of granitic composition. Although samples of the RPG, BG and APG are fairly scattered in the diagrams, they show rough trends. These trends are better defined for $\mathrm{TiO}_{2}$, $\mathrm{Al}_{2} \mathrm{O}_{3}$, ferromagnesian elements, $\mathrm{CaO}, \mathrm{Ba}$ and $\mathrm{Sr}$, and weakly marked for $\mathrm{Na}_{2} \mathrm{O}, \mathrm{K}_{2} \mathrm{O}, \mathrm{Cs}, \mathrm{Rb}, \mathrm{Ba} / \mathrm{Rb}$ and REE. Y shows a sub-horizontal tendency and the $\mathrm{Rb} / \mathrm{Sr}$ ratio a slightly positive tendency. These trends suggest a fractional crystallization process for the RPG, BG and APG, as previously indicated by Sardi et al. $(2010,2011)$. The remaining rocks appear to be unrelated to these trends, particularly in the cases of $\mathrm{TiO}_{2}$, the ferromagnesian elements, $\mathrm{Ba}$ and $\mathrm{Sr}$.

Large-ion lithophile elements such as $\mathrm{Rb}, \mathrm{Sr}$, $\mathrm{Ba}$ and $\mathrm{Cs}$ and their ratios, as well as the REE, are commonly used as monitors of magmatic differentiation (e.g., Halliday et al., 1991; Morteani et al., 1995; Icenhower and London, 1996; Nabelek and Bartlett, 1998; Nabelek, 1999; Jung et al., 2000; Dahlquist et al., 2007). Therefore, we have applied a fractional crystallization model to investigate the behavior of $\mathrm{Rb}, \mathrm{Sr}, \mathrm{Ba}$ and also the REE during this process in the Huaco granite pluton. The used equation is the well-known Rayleigh fractionation: $\mathrm{C}_{1} / \mathrm{C}_{\mathrm{o}}=f^{(\mathrm{D}-1)}$ (taken from Rollinson, 1998), where $\mathrm{C}_{1}$ is the weight concentration of a trace element in the magmatic liquid; $\mathrm{C}_{\mathrm{o}}$ is the weight concentration in the parental liquid, which we consider it to be the BG facies; $f$ is the fraction of melt remaining; and D is the bulk distribution coefficient of the fractionating assemblage during crystal fractionation. The different values of Kd coefficients were taken from Arth (1976), Rapela and Shaw (1979), Nash and Crecraft (1985) and Icenhower and London (1996).

According to the obtained values of $\mathrm{D}\left(\mathrm{D}_{\mathrm{Sr}, \mathrm{Ba}}>1\right.$ and $\mathrm{D}_{\mathrm{Rb}}<1$; Rollinson, 1998), Sr and $\mathrm{Ba}$ are considered "compatible elements" and $\mathrm{Rb}$ as "incompatible" element. The evolutionary models were calculated assuming a starting melt with $285.9 \mathrm{ppm} \mathrm{Rb}$, $318.5 \mathrm{ppm} \mathrm{Ba}$ and $77.5 \mathrm{ppm} \mathrm{Sr}$, which are the average values of the two BG samples. The average values 

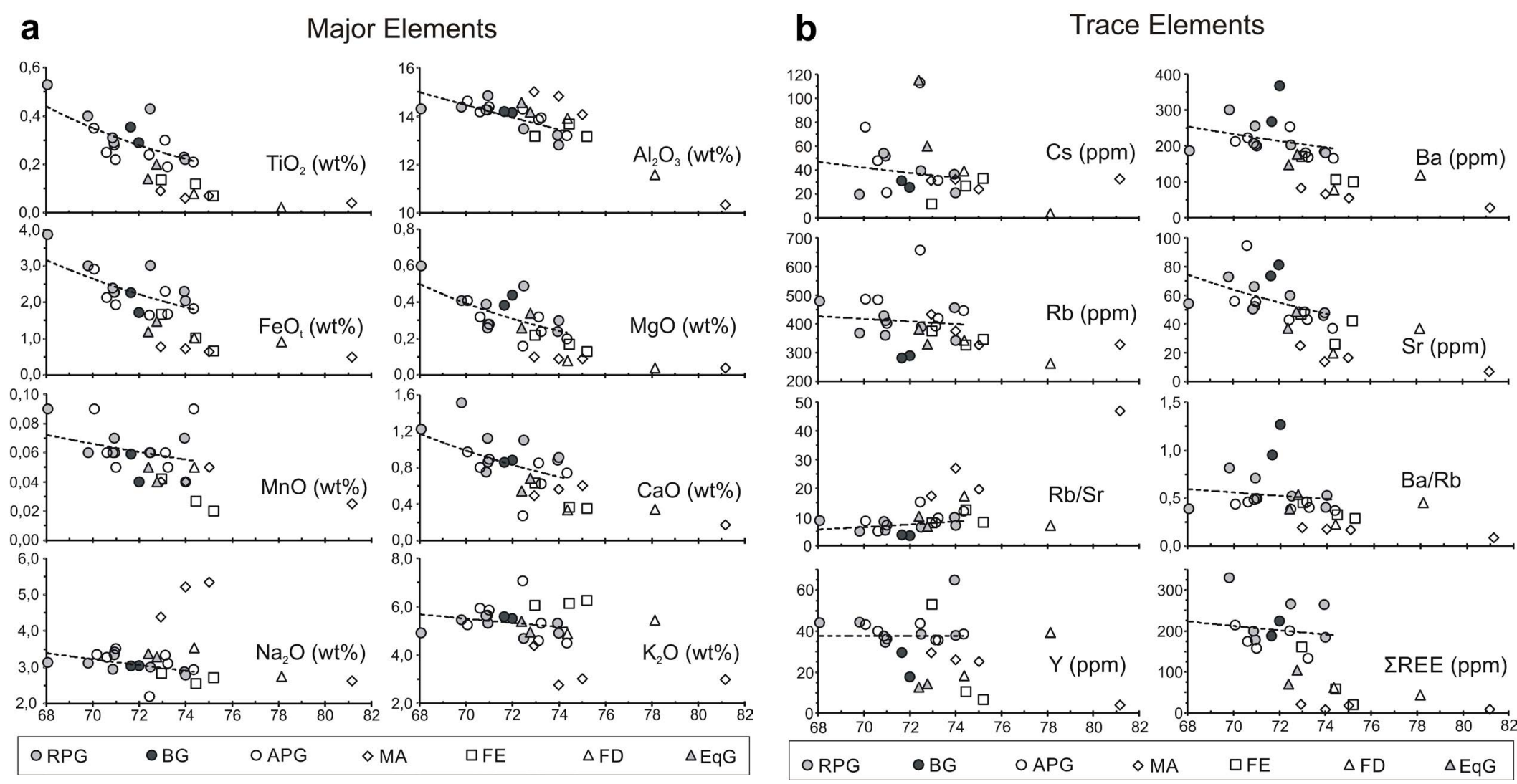

FIG. 8. "Harker" diagrams, with $\mathrm{SiO}_{2}(\mathrm{wt} \%)$ as indicator of differentiation ("x axis") (Only "granitoid" facies and rocks are considered). Variation line is calibrated by least square regressions considering the main and coeval facies (RPG, BG and APG). a. Major elements; b. Trace elements. 
of the BG samples were also used for the REE. The mode of fractionating minerals is also an average value of these samples: $37 \%$ quartz, $26 \% \mathrm{~K}$-feldspar; $29 \%$ plagioclase; $5 \%$ biotite and $3 \%$ muscovite.

Figure 9 show the hypothetical $\mathrm{Rb}, \mathrm{Sr}$ and $\mathrm{Ba}$ compositions in the calculated liquid according to the Rayleigh fractionation model. Comparison between the theoretical compositions and the samples show a correlation for the BG, RPG and APG, whereas the MA, ME, FE, DD, FD and EqG plot away from the theoretical curves, mostly below them. Therefore, we propose that the coeval RPG, BG and APG facies are related to each other by a fractional crystallization process, whereas the other facies and associated rocks were not involved in this process. The REE compositions also show correlation with the fractional crystallization model for the coeval RPG-BG-APG facies, which furthermore have a notable parallelism in the normalized-diagrams (Fig. 10a). Probably due to high contents of REE-fractionated minerals (e.g., biotite), the ME plot close to the theoretical model, but we cannot suggest any relation with the main facies by means of this process, at least given the geochemical data (Fig. 10b). The other facies and associated rocks seem to have no relationship with the fractional crystallization model (Fig. 10a, b, and c).

Given their mostly ellipsoidal shapes and the presence of the APG surrounding them, the BeP probably formed when the main RPG was not fully crystallized. Hence, the BeP can be considered coeval to the final stage of the RPG, rather than an independent event. This also applies to the OG (Grosse et al., 2010). The internal structure of the BeP indicates a progressive sequence of crystallization from the aplitic margins (the MA) towards the interior of the intra-granitic pegmatitic cavity (e.g., Cameron et al., 1949; Černý, 1991; Stilling et al., 1996). The BeP and the OG point to the importance of water and/or volatiles in the late stages of crystallization of the main granite. The formation of the $\mathrm{BeP}$ and its main accessory mineral, beryl, require conditions of water-saturation and the presence of volatiles (Jahns and Burnham, 1969; Evensen et al., 1999). The circulation of water during pegmatitic crystallization is also manifested by the Na-metasomatism present in the pegmatite bodies (Sardi et al., 2015).
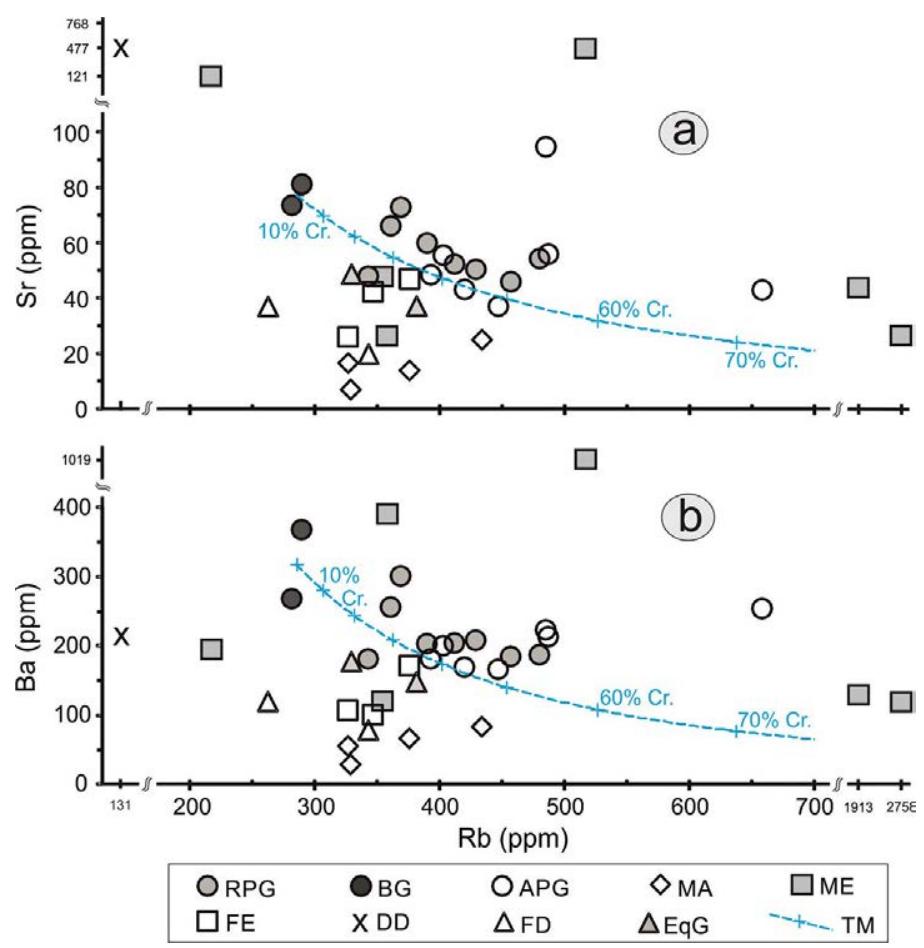

FIG. 9. Sr-Rb (a) and $\mathrm{Ba}-\mathrm{Rb}$ (b) diagrams showing measured contents and theoretical concentrations obtained from the crystal fractionation model. Cr.: crystallization; TM: theoretical model. 

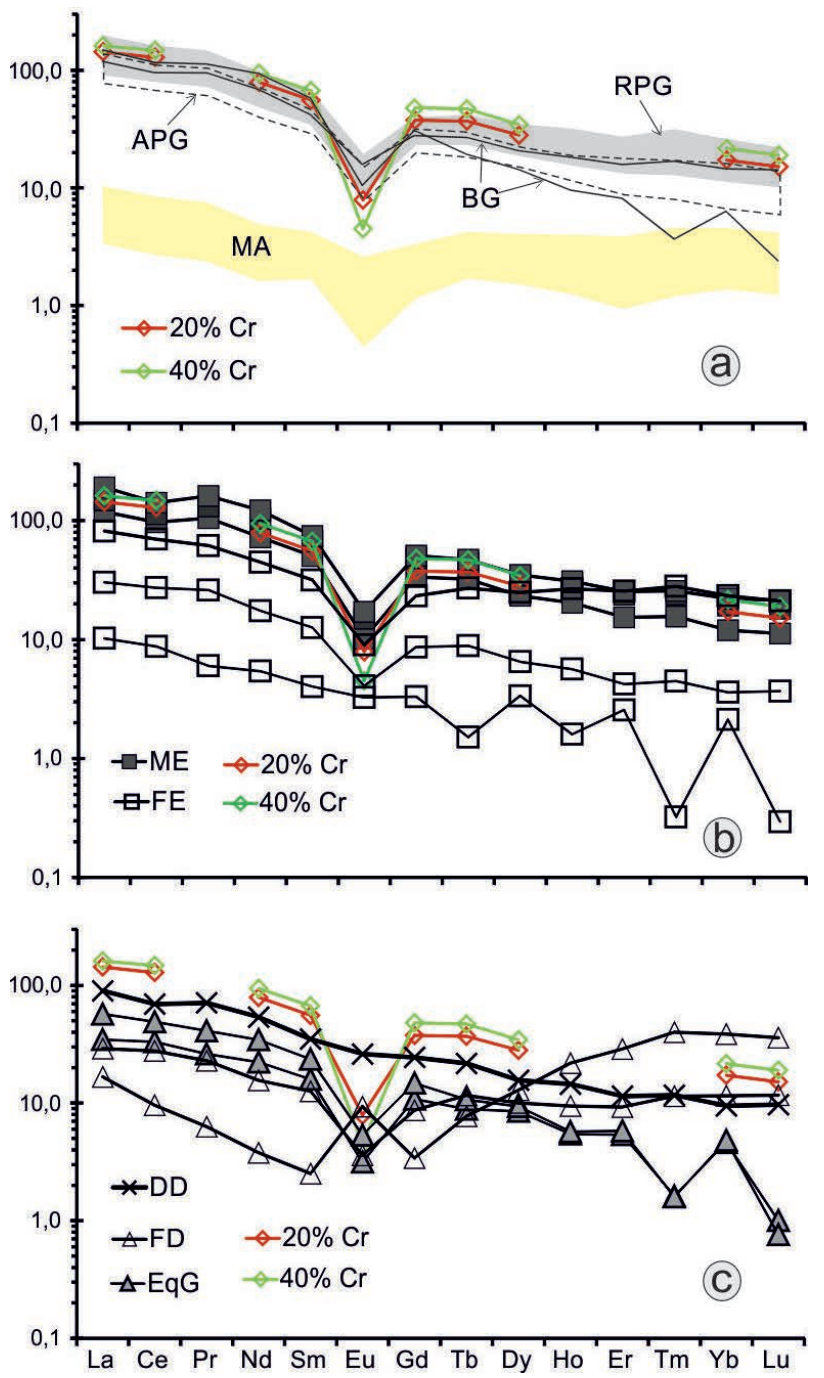

FIG. 10. Chondrite-normalized REE patterns of the different facies of the Huaco granite pluton and associated rocks. a. Main and coeval (to-late) facies: RPG, BG, APG and MA; b. Enclaves: ME and FE; c. Dikes (DD and FD) and Equigranular Granites (EqG). Normalization values after Nakamura (1974). In color calculated patterns, in red $20 \%$ crystallization, in green $40 \%$ crystallization.

Likewise, high water content and its exsolution probably was the driving force for the fomation of the OG (Grosse et al., 2010).

The presence of monazite and other accessory minerals such as apatite can play an important role in LREE fractionation (e.g., Broska et al., 2000; Dahlquist, 2001). Apparently, the behavior of the HREE could have been controlled by the presence of garnet rather than monazite (Duke et al., 1992), as is clearly observed in one sample of the FD. The MA, FE and FD facies with values of $\mathrm{La}_{\mathrm{n}} / \mathrm{Yb}_{\mathrm{n}}$ generally less than 6 , could have formed at a lower temperature than the main regional facies (RPG). The negative Eu anomaly $\left(\mathrm{Eu} / \mathrm{Eu}^{*}<1\right)$ observed in several facies and associated rocks of the Huaco granite pluton can be attributed to the fractionation of feldspars. However, the unique positive Eu anomaly observed in one sample of the FD is attributed to garnet as accessory mineral (Fig. 10c) (e.g., Henderson, 1984).

Features shown by the ME suggest that they are mafic magma globules incorporated into the host 
granite, i.e., rounded or oval shapes, cooling edges, fine to very fine grained texture, incorporation of host magma megacrysts and presence of acicular apatite, indicative of fast cooling and mingling (e.g., Michel et al., 2016). In addition, the ME have higher $\varepsilon N d$ values ( -0.55 and 0.61 ; Grosse et al., $2009)$ than the host granite $\left(\varepsilon \mathrm{Nd}_{\text {Huaco Granite (RPG facies) }}\right.$ -4.27 to -2.10 ; Grosse et al., 2009), suggesting a more primitive source. On the other hand, the ME have high initial ${ }^{87} \mathrm{Sr} /{ }^{86} \mathrm{Sr}$ ratios $(0.8586$ and 0.8680 , Grosse et al., 2009). This decoupling behavior of $\mathrm{Sr}$ and $\mathrm{Nd}$ isotopes is common in enclaves of this type (e.g., Holden et al., 1991; Lesher, 1990 and 1994; Pin et al., 1990; Allen, 1991). Hence, the ME may be considered primitive remnants of the mafic component of the pluton.

The FE can be considered "premature" aplites that formed when partially crystallized granitic magma "breaks" along planes allowing the intrusion of aplites, which are then dismembered due to the movement of the magma. Alternatively, the FE could have been part of a first pulse of felsic magma that crystallized at the margins of the magma chamber and was later dismantled and incorporated by the main granitic magmas. Remnants of these felsic margins could be the felsic facies described by Rossi et al. (2005b) at the eastern border of the Huaco granite pluton.

The occurrence of the DD suggests that they may correspond to an independent/unrelated and younger episode, since this type of dioritic dikes, cutting felsic igneous bodies, is common in extensional post-orogenic settings (e.g., Hegner et al., 1998).

The EqG are temporally younger than the main facies as they contain enclaves of the RPG. Grosse (2007) had suggested that the EqG originated from a purely crustal source and therefore are not final melts of the RPG. A purely crustal source is in agreement with the lack of tonalitic enclaves in the EqG and their chemical compositions similar to experimental melts derived from crustal rocks (e.g., the peraluminous orthogneisses of Holtz and Johannes, 1991; Grosse, 2007).

\section{Conclusions}

The Huaco granite pluton (Velasco Range, northwest Argentina) is composed by one main facies (RPG) and two subordinate facies that are coeval and co-genetic (BG and APG), as well as two coeval- to-late co-genetic facies ( $\mathrm{BeP}$ and $\mathrm{OG})$. In addition, it is host to temporally previous (ME and FE) and posterior (FD, DD and $\mathrm{EqG}$ ) associated rocks.

Based on field observations, petrography, LIL and REE compositions, the main and coeval facies formed by fractional crystallization from the main magma in the sequence BG-RPG-APG, from the wall towards the interior of the chamber and finally around the Be-pegmatites.

The other units had distinct magmatic evolutions: i) the ME are partially assimilated remnants of mafic, mantle-derived components; ii) the FE are remnants of premature aplites or of an initial felsic pulse; iii) the $\mathrm{BeP}, \mathrm{FD}$ and $\mathrm{OG}$ are related to abundant contents of water and/or volatiles and formed during the final stage of crystallization of the main granitic facies (BeP and OG) or after it (FD); iv) the EqG intruded the RPG and seem to have a purely crustal source, suggesting a second batch of fusion without a mafic component (with the exception of the La Chinchilla stock, which has features suggesting a more primitive source); and v) the DD are possibly associated to a younger episode of mafic, mantle-derived magmatism related to extension, although gechemical data is needed to better constrain its origin.

\section{Acknowledgements}

Funding for this project was provided by the following organizations: Consejo Nacional de Investigaciones Científicas y Tecnológicas (CONICET, Argentina), Naruto University of Education, Department of Geosciences (Japan) and Museo Geominero (Instituto Geológico y Minero de España. We thank the reviewers which helped improve the quality of this article. Also, we thank Dr. W. Vivallo for his editorial handling of the manuscript.

\section{References}

Abdel Rahman, A. 1994. Nature of biotite from alkaline, calc-alkaline, and peraluminous magmas. Journal of Petrology 35: 525-541.

Alasino, P.; Dahlquist, J.; Pankhurst, R.; Galindo, C.; Casquet, C.; Rapela, C.; Larrovere, M.; Fanning, C. 2012. Early Carboniferous sub- to mid-alkaline magmatism in the Eastern Sierras Pampeanas, NW Argentina: A record of crustal growth by the incorporation of mantle-derived material in an extensional setting. Gondwana Research 22: 992-1008.

Allen, C. 1991. Local equilibrium of mafic enclaves and granitoids of the Turtle Pluton, southeast California: 
mineral, chemical and isotopic evidence. American Mineralogist 76: 574-588.

Arth, J. 1976. Behaviour of trace elements during magmatic processes -a summary of theroretical models and their applications. Journal of Research of the U.S. Geological Survey 4: 41-47.

Báez, M. 2006. Geología, petrología y geoquímica del basamento ígneo-metamórfico del sector norte de la sierra de Velasco, provincia de La Rioja. Ph.D. Thesis (Unpublished), Universidad Nacional de Córdoba: 207 p.

Báez, M.; Bellos, L.; Grosse, P.; Sardi, F. 2005.Caracterización petrológica de la sierra de Velasco. In Geología de la provincia La Rioja (precámbrico-paleozoico inferior) (Dalhquist, J.; Baldo, E.; Alasino, P.; editors). Asociación Geológica Argentina, Serie D: Publicación especial No.8: 123-130.

Bellos, L. 2005. Geología y petrología del sector austral de la Sierra de Velasco, al sur de los 294' S, La Rioja, Argentina. Serie de Correlación Geológica 19: 261-278.

Bellos, L.; Castro, A.; Díaz-Alvarado, J.; Toselli, A. 2015. Multi-pulse cotectic evolution and in-situ fractionation of calc-alkaline tonalite-granodiorite rocks, Sierra de Velasco batholith, Famatinian belt, Argentina. Gondwana Research 27 (1): 258-280.

Breiter, K.; Müller, A.; Leichmann, J.; Gabaŝová, A. 2005. Textural and chemical evolution of a fractionated granitic system: the Podlesí stock, Czech Republic. Lithos 80: 323-345.

Broska, I.; Petrík, I.; Williams, T. 2000. Coexisting monazite and allanite in peraluminous granitoids of the Tribeč Mountains. Western Carpathians American Mineralogist 85: 22-32.

Cameron, E.; Jahns, R.; McNair, A.; Page, L. 1949. Internal structure of granitic pegmatites. Economic Geology, Monographs 2: 115.

Černý, P. 1991. Rare-element granitic pegmatites. Part I: anatomy and internal evolution of pegmatite deposits and Part II: regional to global environments and petrogenesis. Geoscience Canada 18 (2): 49-81.

Černý, P.; Masau, M.; Goad, B.; Ferreira, K. 2005. The Greer Lake leucogranite, Manitoba, and the origin of lepidolite-subtype granitic pegmatites. Lithos 80 : 305-321.

Collins, W.; Beams, S.; White, A.; Chappell, B. 1982. Nature and origin of A-type granites with particular reference to southeastern Australia. Contrib Mineral Petrol 80: 189-200.

Cravero, O. 2005. Las pegmatitas zonadas de la sierra de Velasco, La Rioja. Serie de Correlación Geológica 19: 133-144.
Dahlquist, J. 2001. REE fractionation by accessory minerals in epidote-bearing metaluminous granitoids from the Sierras Pampeanas, Argentina. Mineralogical Magazine 65 (4): 463-475.

Dahlquist, J.; Pankhurst, R.; Rapela, C.; Casquet, C.; Fanning, C.; Alasino, P.; Báez, M. 2006. The San Blas Pluton: An example of Carboniferous plutonism in the Sierras Pampeanas, Argentina. Journal of South American Earth Sciences 20: 341-350.

Dahlquist, J.; Galindo, C.; Pankhurst, R.; Rapela, C.; Alasino, P.; Saavedra, J.; Fanning, C. 2007. Magmatic evolution of the Peñon Rosado granite: Petrogenesis of garnet-bearing granitoids. Lithos 95: 177-207.

Dahlquist, J.; Alasino, P.; Eby, N.; Galindo, C.; Casquet, C. 2010. Fault controlled Carboniferous A-type magmatism in the proto-Andean foreland (Sierras Pampeanas, Argentina): Geochemical Constraints and Petrogenesis. Lithos 115: 65-81.

Dahlquist, J.; Pankhurst, R.; Gaschnig, R.; Rapela, C.; Casquet, C.; Alasino, P.; Galindo, C.; Baldo, E. 2013. $\mathrm{Hf}$ and $\mathrm{Nd}$ isotopes in Early Ordovician to Early Carboniferous granites as monitors of crustal growth in the Proto-Andean margin of Gondwana. Gondwana Research 23: 1617-1630.

Dall'Agnol, R.; Oliveira, D. 2007. Oxidized, magnetiteseries, rapakivi-type granites of Carajás, Brazil: Implications for classification and petrogenesis of A-type granites. Lithos 93: 215-233.

De Los Hoyos, C.; Willner, A.; Larrovere, M.; Rossi, J.; Toselli, A.; Basei, M. 2011. Tectonothermal evolution and exhumation history of the Paleozoic Proto-Andean Gondwana margin crust: The Famatinian Belt in NW Argentina. Gondwana Research 20: 309-324.

Duke, E.; Papike, J.; Laul, J. 1992. Geochemistry of a boron-rich peraluminous granite pluton: The Calamity Peak Layered granite-pegmatite complex, Black Hill, South Dakota. Canadian Mineralogist 30: 811-833.

Eby, G. 1990. The A-type granitoids: a review of their occurrence and chemical characteristics and speculations on their petrogenesis. Lithos 26:115-134.

Eby, G. 1992. Chemical subdivision of the A-type granitoids: petrogenetic and tectonic implications. Geology 20: 641-644.

Evensen, J.; London, D.; Wendlandt, R. 1999. Solubility and stability of beryl in granitic melts. American Mineralogist 84: 733-745.

Frost, B.; Barnes, C.; Collins, W.; Arculus, R.; Ellis, D.; Frost, C. 2001. A geochemical classification for granitic rocks. Journal of Petrology 42: 2033-2048. 
González Bonorino, F. 1951. Una nueva formación Precámbrica en el noroeste Argentino. Comunicación Científica, Museo de La Plata 5: 4-6.

Grosse, P. 2007. Los granitos porfíricos y orbiculares del sector Centro-Oriental de la Sierra de Velasco. Génesis y significación regional. Provincia de la Rioja. R. Argentina (Unpublished) Ph.D. Thesis, Universidad Nacional de Córdoba: 285 p.

Grosse, P.; Sardi, F. 2005. Geología de los granitos Huaco y Sanagasta, sector centro-oriental de la Sierra de Velasco, La Rioja. Serie de Correlación Geológica 19: 221-238.

Grosse, P.; Bellos, L.; Báez, M.; Rossi, J.; Toselli, A. 2003. Ordovician magmatism of the Sierra de Velasco, La Rioja, Argentina. Serie de Correlación Geológica 17: 223-226.

Grosse, P.; Larrovere, M.; De la Rosa, J.D.; Castro, A. 2005. Petrología y origen del stock La Chinchilla, Sierra de Velasco, La Rioja (Argentina). In Congreso Geológico Argentino, No. 16, Acta 1: 533-538. Buenos Aires.

Grosse, P.; Rossi, J.N.; Sardi, F.; Toselli, A. 2006. Química mineral de los granitos Sanagasta, Huaco y La Chinchilla, Sierra de Velasco, La Rioja, Argentina. In Congreso de Mineralogía y Metalogenia, No. 8, Actas: 381-388. Buenos Aires.

Grosse, P.; Söllner, F.; Báez, M.; Toselli, A.; Rossi, J.; De la Rosa, D. 2009. Lower Carboniferous post-orogenic granites in central-eastern Sierra de Velasco, Sierras Pampeanas, Argentina: U-Pb monazite geochronology, geochemistry and $\mathrm{Sr}-\mathrm{Nd}$ isotopes. The International Journal of Earth Sciences 98: 1001-1025.

Grosse, P.; Toselli, A.; Rossi, J. 2010. Petrology and geochemistry of the orbicular granitoid of Sierra de Velasco (NW Argentina) and implications for the origin of orbicular rocks. Geological Magazine 147: 451-468.

Grosse, P.; Bellos, L.; De Los Hoyos, C.; Larrovere, M.; Rossi, J.; Toselli, A. 2011. Across-arc variation of the Famatinian magmatic arc (NW Argentina) exemplified by I-, S- and transitional I/S-type Early Ordovician granitoids of the Sierra de Velasco. Journal of South American Earth Sciences 32: 110-126.

Halliday, A.; Davidson, J.; Hildreth, W.; Holden, P. 1991. Modelling the petrogenesis of high $\mathrm{Rb} / \mathrm{Sr}$ silicic magmas. Chemical Geology 92: 107-114.

Hegner, E.; Kölbl-Ebert, M.; Loeschke, J. 1998. Postcollisional Variscan lamprophyres (Black Forest, Germany): ${ }^{40} \mathrm{Ar} /{ }^{39} \mathrm{Ar}$ phlogopite dating, $\mathrm{Nd}, \mathrm{Pb}, \mathrm{Sr}$ isotope and trace elements characteristics. Lithos 45: 395-411.
Henderson, P. 1984. Rare Earth Elements Geochemistry. Elsevier: 510 p.

Höckenreimer, M.; Söllner, F.; Miller, H. 2003. Dating the TIPA shear zone: Early Devonian terrane boundary between Famatinian and Pampean systems (NW Argentina). Journal of South American Earth Sciences 16 (1): 45-66.

Holden, P.; Halliday, A.; Stephens, W.; Henney, P. 1991. Chemical and isotopic evidence for major mass transfer between mafic enclaves and felsic magma. Chemical Geology 92: 135-152.

Holtz, F.; Johannes, W. 1991. Genesis of peraluminous granites I. Experimental investigation of melt compositions at 3 and $5 \mathrm{~kb}$ and various $\mathrm{H}_{2} \mathrm{O}$ activities. Journal of Petrology 32: 935-958.

Icenhower, J.; London, D. 1996. Experimental partitioning of $\mathrm{Rb}, \mathrm{Cs}, \mathrm{Sr}$, and $\mathrm{Ba}$ between alkali feldspar and peraluminous melt. American Mineralogist 81: 719-734.

Jahns, R.; Burnham, C. 1969. Experimental studies of pegmatite genesis: I. A model for the derivation and crystallization of granitic pegmatites. Economic Geology 64: 843-864.

Jung, S.; Hoernes, S.; Mezger, K. 2000. Geochronology and petrogenesis of Pan-African, syn-tectonic, S-type and post-tectonic A-type granite (Namibia): products of melting of crustal sources, fractional crystallization and wall rock entrainment. Lithos 50: 259-287.

Larrovere, M.; De Los Hoyos, C.; Toselli, A.; Rossi, J.; Basei, M.; Belmar, M. 2011. High T/P evolution and metamorphic ages of the migmatitic basement of northern Sierras Pampeanas, Argentina: Characterization of a mid-crustal segment of the Famatinian belt. Journal of South American Earth Sciences 31: 279-297.

Larrovere, M.; De Los Hoyos, C.; Grosse, P. 2012. Los complejos metamórficos del retro-arco Famatiniano (noroeste de Argentina): caracterización geoquímica e isotópica de sus protolitos e implicancias geotectónicas. Revista Mexicana de Ciencias Geológicas 29 (3): 676-695.

Lesher, C. 1990. Decoupling of chemical and isotopic exchange during magma mixing. Nature 344: 235-237.

Lesher, C. 1994. Kinetics of Sr and Nd exchange in silicate liquids: theory, experiments, and applications to uphill diffusion, isotopic equilibration, and irreversible mixing magma. Journal of Geophysical Research 99: 9585-9604.

Macchioli Grande, M.; Alasino, P.H.; Rocher, S.; Larrovere, M.A.; Dahlquist, J.A. 2015. Asymmetric textural and structural patterns of a granitic body emplaced at shallow levels: The La Chinchilla pluton, northwestern 
Argentina. Journal of South American Earth Sciences 64: 58-68.

Michel, L.; Wenzel, T.; Markl, G. 2016. Interaction between two contrasting magmas in the Albtal pluton (Schwarzwald, SW Germany): textural and mineralchemical evidence. International Journal of Earth Science 5: 1505-1524.

Morello, O.; Aparicio González, P. 2013. Mineralización de uranio en la sierra de Velasco, La Rioja. Revista de la Asociación Geológica Argentina 70 (3): 335-340.

Morteani, G.; Preinfalk, C.; Spiegel, W.; Bonalumi, A. 1995. The Achala Granitic Complex and the Pegmatites of the Sierras Pampeanas (Northwest Argentina): A study of differentiation. Economic Geology 90: 636-647.

Muñoz, J. 1984. F-OH and Cl-OH exchange in micas with applications to hydrothermal ore deposits. In Reviews in Mineralogy, Micas (Bailey, S.; editors). Mineralogical Society of America 13: 469-493.

Nakamura, N. 1974. Determination of REE, Ba, Mg, $\mathrm{Na}$ and $\mathrm{K}$ in carbonaceous and ordinary chondrites. Geochimica et Cosmochimica Acta 38: 757-773.

Nash, W.; Crecraft, H. 1985. Partition coefficients for trace elements in silicic magmas. Geochimica et Cosmochimica Acta 49: 2309-2322.

Nabelek, P. 1999. Trace element distribution among rockforming minerals in Black Hills migmatites,South Dakota: A case for solid-state equilibrium. American Mineralogist 84: 1256-1269.

Nabelek, P.; Bartlett, C. 1998. Petrologic and geochemical links between the post-collisional Proterozoic Harney Peak leucogranite, South Dakota, USA, and its source rocks. Lithos 45: 71-85.

Pankhurst, R.J.; Rapela, C.; Saavedra, J.; Baldo, E.G.; Dahlquist, J.; Pascua, I.; Fanning, C.M. 1998. The Famatinian arc in the central Sierras Pampeanas: an early to mid-Ordovician continental arc on the Gondwana margin. In The Proto-Andean Margin of Gondwana (Pankhurst, R.J.; Rapela, C.; editors). Geological Society of London, Special Publication 142: 343-367.

Pankhurst, R.J.; Rapela, C.; Fanning, C. 2000. Age and origin of coeval TTG, I- and S- type granites in the Famatinian belt of NW Argentina. Transactions of the Royal Society of Edinburgh: Earth Sciences 91: 151-168.

Parra, F.; Blason, R.; Álvarez, J.; Zarco Ambrosio, J.; Bello, C. 2011. Estimación de recursos uraníferos en el Stock La Chinchilla, sierra de Velasco, provincia de La Rioja. In Congreso Geológico Argentino, No. 18, Proceeding: CD-Room (2 pages).
Pin, C.; Binon, M.; Belin, J.; Barbarin, B.; Clemens, J. 1990. Origin of microgranular enclaves in granitoids: equivocal $\mathrm{Sr}-\mathrm{Nd}$ evidence from Hercynian rocks in the Massif Central (France). Journal of Geophysical Research 95: 17821-17828.

Quartino, B.; Villar Fabre, J. 1962. El cuerpo granítico orbicular precámbrico de la Pampa de Los Altos, sierra de Velasco. Revista de la Asociación Geológica Argentina 18: 11-41.

Rapela, C.; Shaw, D. 1979. Trace and major element models of granitoid genesis in the Pampean Ranges, Argentina. Geochimica et Cosmochimica Acta 43: 1117-1129.

Rapela, C.; Casquet, C.; Baldo, E.; Dahlquist, J.; Pankhurst, R.; Galindo, C.; Saavedra, J. 2001. Las Orogénesis del Paleozoico Inferior en el margen proto-andino de América del Sur, Sierras Pampeanas, Argentina. Journal of Iberian Geology 27: 23-41.

Rollinson, H. 1998. Using geochemical data: evaluation, presentation, interpretation. Longman: p. 352.

Rossi, J.; Willner, A.; Toselli, A. 2002. Ordovician Metamorphism of the Sierras Pampeanas, Sistema de Famatina and Cordillera Oriental, Northwestern Argentina. Serie de Correlación Geológica 16: 225 242.

Rossi, J.; Toselli, A.; Báez, M. 2005a. Evolución termobárica del ortogneis peraluminoso del noroeste de la sierra de Velasco, La Rioja. Asociación Geológica Argentina, Revista 60: 278-289.

Rossi, J.; Toselli, A.; Prieri, A.; Cravero, O.; De Los Hoyos, C. 2005b. Granitos cordieríticos y corneanas del flanco oriental de la sierra de Velasco, La Rioja, República Argentina. In Congreso Geológico Argentino, No. 16, Proceedings: CD-Room (4 pages).

Salvatore, M.; Parra, F.; Sánchez, D.; Álvarez, J.; Bello, C.; Zarco Ambrosio, J. 2011. Mapeo detallado de facies graníticas en el Stock uranífero La Chinchilla, sierra de Velasco, provincia de La Rioja. In Congreso Geológico Argentino, No. 18, Proceeding CD-Room: 2 p.

Salvatore, M.; Parra, F.; Sánchez, D.; Álvarez, J.; Bello, C.; Zarco Ambrosio, J. 2013. Caracterización litogeoquímica del granito La Chinchilla y su relación con el uranio, sierra de Velasco, Provincia de La Rioja. Revista de la Asociación Geológica Argentina 70 (3): 341-350.

Sardi, F.; Toselli, A.; Rossi de Toselli, J.N. 2002. Estudio geológico preliminar de las pegmatitas del Norte del Bolsón de Huaco, sierra de Velasco, La Rioja. In Congreso Geológico Argentino, No. 15 (Cabaleri, N.; Cingolani, C.; Linares, E.; López de Luchi, M.; Ostera, H.; Panarello, H.; editors). Actas 2: 33-34. El Calafate. 
Sardi, F.; Murata, M.; Grosse, P. 2010. Petrographical and geochemical features of the granite-pegmatite transition in the Velasco Pegmatitic District, NW Argentina. Neues Jahrbuch für Geologie und Paläontologie 258: 61-71.

Sardi, F.; Murata, M.; Grosse, P. 2011. Magmatic differentiation in the Huaco granite and its associated Be-pegmatites from the Velasco district, Argentina. In International Symposium on Granitic Pegmatites, No. 5, Abstract book: 189-191. Mendoza.

Sardi, F.G.; Heimann, A.; Sarapura Martínez, J. 2015. Geología local y mineralogía accesoria de las pegmatitas berilíferas del Distrito Velasco y rocas graníticas asociadas, Provincia Pegmatítica Pampeana, Noroeste de Argentina. Serie de Correlación Geológica 31 (1): 111-132.

Smith, D.; Noblett, J.; Wobus, R.; Unruh, D.; Douglass, J.; Beance, R.; Davis, C.; Goldman, S.; Kay, G.; Gustavson, B.; Saltoun, B.; Stewart, J. 1999. Petrology and geochemistry of late-stage intrusions of the A-type, mid-Proterozoic Pikes Peak batholith (Central Colorado, USA): implications for petrogenetic models. Precambrian Research 98: 271-305.

Stilling, A.; Černý, P.; Vanstone, P. 2006. The Tanco pegmatite at Bernic Lake, Manitoba. XVI. Zonal and bulk compositions and their petrogenetic significance. The Canadian Mineralogist 44: 599-623.

Toselli, A.; Rossi, J.; Aceñolaza, F. 1986. A proposal for the systematization of the Upper-Pre-cambrian, Lower Paleozoic basement in the Pampean Ranges, Argentina. Zentralblatt für Geologie und Paläontologie 1 (9-10): 1227-1233.

Toselli, A.; Sial, A.; Rossi, J. 2002. Ordovician magmatism of the Sierras Pampeanas, Sistema de Famatina and Cordillera Oriental, NW of Argentina. Serie de Correlación Geológica 16: 313-326.

Toselli, A.; Rossi, J.; Miller, H.; Báez, M.; Grosse, P.; López, J.; Bellos, L. 2005. Las rocas graníticas y metamórficas de la Sierra de Velasco. Serie de Correlación Geológica 19: 211-220.

Toselli, A.; Rossi, J.; Báez, M.; Grosse, P.; Sardi, F. 2006. El Batolito Carbonífero Aimogasta, Sierra de Velasco,
La Rioja, Argentina. Serie de Correlación Geológica 21: 137-154.

Toselli, A.; Miller, H.; Aceñolaza, F.; Rossi, J.; Söllner, F. 2007. The Sierra de Velasco (northwestern Argentina) - an example for polyphase magmatism at the margin of Gondwana. Neues Jahrbuch für Geologie und Paläontologie 246 (7): 325-345.

Toselli, A.; Rossi, J.; Basei, M.; Larrovere, M. 2011. Controles geoquímicos e isotópicos en la petrogénesis de los granitos Devónico-Carboníferos Santa Cruz y Asha: Sierra de Velasco, Argentina. Serie Correlación Geológica 27 (2): 77-98.

Verdecchia, S.O. 2009. Las metamorfitas de baja presión vinculadas al arco magmático Famatiniano: las unidades metamórficas de la Quebrada de La Cébila y el borde oriental del Velasco. Provincia de La Rioja-Argentina. Ph.D. (Unpublished), Thesis, Universidad Nacional de Córdoba: 312 p.

Verdecchia, S.; Baldo, E. 2010. Geoquímica y procedencia de los metasedimentos ordovícicos delcomplejo metamórfico La Cébila, provincia de La Rioja, Argentina. Revista Mexicana de Ciencias Geológicas 27: 97-111.

Verdecchia, S.O.; Baldo, E.G.; Benedetto, J.L.; Borghi, P.A. 2007. The first shelly faunas from metamorphic rocks of the Sierras Pampeanas (La Cébila Formation, Sierra de Ambato, Argentina): age and paleogeographic implications. Ameghiniana 44: 493-498.

Verdecchia, S.; Casquet, C.; Baldo, E.; Pankhurst, R.; Rapela, C.; Fanning, M.; Galindo, C. 2011. Mid- to Late Cambrian docking of the Río de La Plata craton to southwestern Gondwana: age constraints from U-Pb SHRIMP detrital zircon ages from Sierras de Ambato and Velasco (Sierras Pampeanas, Argentina). Journal of the Geological Society 168: 1061-1071. London.

Vernon, R. 1986. K-feldspar megacrysts in granites phenocrysts, not porphyroblasts. Earth Science Reviews 23: 1-63.

Whalen, J.; Currie, K.; Chappell, B.1987. A-type granites: geochemical characteristics, discrimination and petrogenesis. Contribution Mineral Petrol 95: 407-419.

Manuscript received: November 28, 2016; revised/accepted: November 11, 2017; available online: January 31, 2018. 